\title{
COVID-19, AGAMA, DAN SAINS
}

\author{
Musa Maliki \\ Universitas Pembangunan Veteran Jakarta \\ musa_maliki@yahoo.com
}

\section{Abstrak}

Tulisan ini memaparkan tentang discourse kelompok beragama yang ignore terhadap Covid-19. Ada anggapan dari mainstream umat beragama bahwa kelompok ini tidak menggunakan akalnya tetapi menggunakan egonya sehingga mempunyai implikasi sosial yakni menularkan virus SARS-CoV-2 ke orang-orang di dekatnya. Singkatnya kelompok ini konservatif dan 'anti-sains'. Tulisan ini memberi perspektif yang berbeda bahwa kaum beragama yang ignore terhadap Covid-19 menggunakan agama demi melindungi dirinya atau demi kepentingan survival-nya di level eksistensial dari represi discourse modernkapitalisme. Problemnya, discourse kelompok ignorance ini justru melegitimasi (membenarkan) discourse politik sekuler Barat yang telah mengandangkan agama ke 'agama' dalam definisi yang dikonstruksikannya. Padahal, dalam Islam, Ilmuwan Muslim terdahulu menjalankan hidup asketismenya justru melalui jalur sains demi mencari kebenaran Allah yang mewujud pada alam semesta (ayat kauniyah). Di sini ada sinergi dan keselerasan antara sains dan spiritualisme, yang ukhrawi dan yang duniawi (secular), transcendental dan immanent. Oleh sebab itu, hal yang penting adalah proses penghayatan keberagamaan selalu harus diawali dengan disiplin ketat dalam mempelajari agama secara bertahan, tidak serampangan dan melompat-lompat atau terus belajar kepada para ahlinya, bukan dengan 'demokratisasi' agama.

Kata kunci : Covid-19, agama, sains, kedokteran, ilmuwan Muslim 


\section{Pendahuluan}

Bagaimana relevansi agama dan sains dalam menghadapi pandemi Covid-19? Mengapa agama dewasa ini -dalam hal ini umat beragama masih ada (walaupun bukan mayoritas) yang bersikap seolah-olah ignorance (Jahiliya) terhadap pandemi Covid-19 dan ada pula umat beragama yang memiliki logika dan terminologinya sendiri? Apakah pemahaman konservatisme menghasilkan pemisahan antara agama dan ilmu pengetahuan (sains)? Pertanyaan ini tentunya tidak mengupas penjelasan teknis biologi tentang apa itu virus dan seluk beluknya serta bagaimana ilmu kesehatan masyarakat menyikapi virus tersebut.

Artikel ini berusaha melihat konstruksi cara berpikir keberagamaan, khususnya Islam di masa pandemik Covid-19. Tentunya banyak logika dan terminologi agama tertentu dalam menghadapi tantangan pandemik Covid-19 yang seringkali tidak relevan dengan logika dan terminologi sains. Misalnya dalam logika dan terminologi sains, "Covid-19" adalah wabah/penyakit menular (infectious disease) yang bersumber dari virus bernama SARS-CoV-2114 sedangkan dalam logika dan terminologi (beberapa tafsir Muslim) agama Islam, Covid-19 dibahasakan sebagai “tentara Allah SWT/virus korona tentara Allah”. Tentara Allah dimaksudkan menyerang Cina yang telah melukai umat Islam Uighur ${ }^{115}$; ada pula logika dan terminologi agama Islam lainnya, "ujian dan peringatan Allah". Hal ini dimaksudkan agar manusia sadar untuk tidak angkuh. ${ }^{116}$ Sekelumit fakta yang berbeda-beda ini membuat muncul pemahaman bahwa agama dan sains masing-masing berdiri sendiri secara esensial. Dalam Islam, fakta ini problematis.

Penelitian ini berusaha membongkar konstruksi logika dan terminologi agama dan sains esensialis semacam itu. Sikap tidak peduli terhadap sains dan sebaliknya adalah sikap kontra produktif (counter-productive). Walaupun keduanya mempunyai ekspresi bahasa yang berbeda, tetapi keduanya tidak perlu dipisahkan atau bahkan dipertentangkan lalu berdiri sendiri-sendiri.

114. Wen-Hua Kong, Yao Li, Ming-Wei Peng, De-Guang Kong, Xiao-Bing Yang, Leyi Wang, dan Man-Qing Liu, "SARS-CoV-2 detection in patients with influenza-like illness", Nat Microbiol (2020), https://doi. org/10.1038/s41564-020-0713-1, diakses 13 April 2020.

115. Muhammad Ilham Nafi'an, "Ustaz Somad Beri Penjelasan soal Anggapan 'Virus Corona Tentara Allah", https://news.detik.com/berita/d-4920843/ustaz-somad-beri-penjelasan-soal-anggapan-virus-coronatentara-allah diakses 13 April 2020; "MUI Bela Ustaz Abdul Somad soal Corona Tentara Allah", https:// www.tagar.id/mui-bela-ustaz-abdul-somad-soal-corona-tentara-allah, diakses 13 April 2020; Jacobus E. Lato, "Coronavirus: God's Army and Pork Consumption in Indonesia", https://www.gatestoneinstitute. org/15822/coronavirus-indonesia, diakses 13 April 2020; Kate Walton, "Wuhan Virus Boosts Indonesian Anti-Chinese Conspiracies", https://foreignpolicy.com/2020/01/31/wuhan-coronavirus-boosts-indonesiananti-chinese-conspiracies/.

116. M. Alvin Nur Choironi, “Quraish Shihab: Saya Tidak Setuju Pendapat Corona Tentara Allah”, https://islami. co/quraish-shihab-tidak-setuju-pendapat-corona-tentara-allah/, diakses 13 April 2020. 
Dari logika dan terminologi yang berbeda antara sains dan agama, keduanya memiliki irisan dan shared values dalam prinsip-prinsip universal, dan substansi yang sama, yakni keberlangsungan hidup umat manusia bersama alam semesta (planetary). Agar tidak terjebak pada discourse mempertentangkan agama dan sains, kita perlu memiliki pemahaman yang proporsional dan komprehensif atas keduanya yang dimiliki oleh para ilmuwan Islam terdahulu.

Dalam hal ini, penelitian tidak mempromosikan humanisme (Eropa) esensial, tetapi keharmonisan alam. Hal ini amat sangat signifikan sebab seringkali logika dan terminologi humanisme (modern) justru menjauhkan makna terdalam keberagamaan demi mengejar totalisme sains dan rasionalisme-abstraksi.

Penelitian ini juga tidak mempromosikan skriptualisme esensial sebab hal ini menyebabkan pemaksakan realitas baru (konteks) terhadap realitas lama (teks). Terkait hal ini, artikel ini akan fokus pada Islam sesuai dengan keterbatasan penulis. Selain itu, saya tidak akan masuk ke wilayah interpretasi teologi yang sudah tidak ada pintu dialektika. Berbagai macam interpretasi al Quran dikomprehensifkan dalam gambarkan besar argumen intelektual Islam yang terkait dengan pembahasan, bukan tafsir pribadi saya dalam melakukan interpretasi semena-mena. Hal ini sekaligus memberi pemahaman kepada pembaca bahwa studi ini berada dalam konteks multidisipliner dengan konsentrasi filsafat, ilmu sosial, politik, sejarah dan humaniora.

Untuk mempermudah penjabaran artikel ini, pertama saya akan memberikan konteks Covid-19 terlebih dahulu agar problem keberagamaan di masa Covid-19 ini pada akhirnya menjadi refleksi sejarah di masa depan. Di sini saya juga akan menempatkan perilaku keberagamaan di beberapa negara dalam menghadapi masalah Covid-19. Kedua, memaparkan keterkaitan antara discourse keberagamaan tersebut dengan discourse sekularisme, khususnya pemisahan antara agama dan sains. Bagaimana sejarah sekularisme 'mengandangkan' agama di dalam 'agama' itu sendiri dan sains diperuntukkan sains sendiri -dalam pengertian modernissekuler. Hal inilah yang mereduksi pemahaman agama, khususnya Islam di masa Covid-19 sebagai entitas di luar ilmu pengetahuan, khususnya entitas Covid-19 (agama reduksionis). Ketiga, Sains dalam Islam. Sains sendiri adalah bagian dari Islam, from within. Islam sendiri menginspirasi sains. Islam adalah kompas sains. Tanpa Islam, sains menjadi tunggang langgang sedangkan tanpa sains, 'Islam' mengalami kejumudan (conservative) dan menciptakan masyarakat ignorance (Jahiliya). Keempat, pada akhir artikel ini, saya menekankan kembali kontribusi agama dalam menentukan sains dan sebaliknya. 


\section{Konteks Keberagamaan di Masa Covid-19}

Awalnya, Covid-19 (Coronavirus disease - 2019) adalah salah satu penyakit dari satu jenis virus Korona yang bernama SARS-CoV-2 yang muncul di pasar makanan laut Hunan, Wuhan, Cina, Desember 2019117. Diprediksikan vaksin dapat diproduksi lebih dari setahun. Kompleksitas permasalahan tetap tak terselesaikan segera sebab akan muncul lagi permasalahan lain seperti keterbatasan vaksin dan perebutan vaksin antara negara kaya dan negara miskin/ berkembang dan penentuan siapa-siapa yang paling utama membutuhkan ${ }^{118}$.

Pada 11 Maret 2020, World Health Organization (WHO) mengumumkan Covid-19 sebagai pandemi, yakni wabah yang mengglobal ${ }^{119}$. Menurut WHO, kasus Covid-19 ini adalah yang pertama kalinya diumumkan sebagai pandemi serta belum ada yang bisa mengatasinya (control) ${ }^{120}$. Dari Januari sampai Maret 2020, penelitian tentang Covid-19 sudah mencapai 900 artikel dan terus berkembang ${ }^{121}$. Hal ini membuktikan bahwa pandemi ini sangat berbahaya dan para ilmuwan masih saja menelitinya.

WHO dan para ahli sains menyarankan langkah dasar aman dari Covid-19: Pertama, social distancing/physical distancing (satu meter berbicara dengan orang lain). Kedua, cuci tangan sesering mungkin, karena virus dapat hinggap pada apapun yang kita sentuh. Ketiga, menghindari menyentuh mata, hidung, dan mulut. Semua itu adalah tempat masuk virus ke dalam bagian lemah kita, khususnya paru-paru yang membuat kita sesak nafas. Keempat, menutup hidung dan mulut kita dengan masker yang sesuai standar. Memakai masker tidak

117. Di pasar tersebut biasa dijual makanan seperti ular, kelelawar, anjing, katak, burung, marmut, dan kelinci. Penelitian mengatakan bahwa infeksi yang terjadi dimungkinkan pintu penularannya berasal dari hewanhewan tersebut ke manusia, lalu selanjutnya penyebarannya secara meluas justru tidak terkait dengan binatang-binatang tersebut tetapi dari manusia ke manusia. Penyebarannya dari droplet yang keluar dari batuk, bersin, dan air liur serta bersentuhan dengan anggota badan yang terpapar droplet tersebut atau yang disentuhnya dan kemudian berpindah kepada orang lain melalui hidung atau mulut. Walaupun sumber dari binatang (the zoonotic source of SARS-CoV-2) belum bisa dikonfirmasi, tetapi sequence-based analysis mengatakan bahwa kelelawar adalah 'pembawa' virus yang berbahaya itu. Lihat Muhammad Adnan Shereen, Suliman Khan, Abeer Kazmi, Nadia Bashir, Rabeea Siddique, "COVID-19 infection: Origin, transmission, and characteristics of human coronaviruses", Journal of Advance Research, Vol 24, 2020, hlm, 91-98, diakses https://doi.org/10.1016/j.jare.2020.03.005.

118. Roxanne Khamsi, "If coronavirus vaccine arrives, can the world make enough?" https://www.nature.com/ articles/d41586-020-01063-8 diakses 13 April 2020; Elissa Prichep, "Why a coronavirus vaccine takes over a year to produce - and why that is incredibly fast", https://www.weforum.org/agenda/2020/04/why-acoronavirus-vaccine-takes-over-a-year-to-produce-and-why-that-is-incredibly-fast/, diakses 13 April 2020.

119. Menurut WHO, istilah pandemi ini bukanlah kata yang digunakan secara serampangan, karena jika disalahgunakan maka "can cause unreasonable fear, or unjustified acceptance that the fight is over, leading to unnecessary suffering and death". Lihat "WHO Director-General's opening remarks at the media briefing on COVID-19 - 11 March 2020" https://www.who.int/dg/speeches/detail/who-director-general-sopening-remarks-at-the-media-briefing-on-covid-19---11-march-2020, diakses 13 April 2020.

120. Ibid

121. Ewen Callaway, David Cyranoski, Smriti Mallapaty, Emma Stoye, Jeff Tollefson, The corona virus pandemic in five powerful chats," https://www.nature.com/articles/d41586-020-00758-2, diakses 14 April 2020. 
hanya melindungi diri kita dari penularan virus tetapi juga melindungi orangorang di sekitar kita sebab terdapat kemungkinan kita sendiri telah terkena virus tanpa mengetahuinya. Orang yang masih terlihat sehat bisa saja menularkannya karena telah membawa virus tersebut. Oleh karenanya, jarak dan masker amat sangat penting. Kelima, jika demam, badan sakit-sakit (nggreges), dan sesak nafas, segeralah periksa ke dokter sesuai dengan prosedur yang sudah dirancang pihak otoritas kesehatan di tempat kita tinggal. Kelima, ikuti terus informasi yang berkembang di level lokal, nasional dan internasional. Keenam, bagi yang berpindah-pindah, khususnya lintas negara atau lintas daerah, maka harus mengisolasi diri (self-isolation/ quarantine) selama minimal empat belas hari. Empat belas hari adalah standar durasi kita bisa mendeteksi virus di dalam tubuh seseorang. Terakhir, terus menjaga kekebalan tubuh agar tidak mudah terserang penyakit ${ }^{122}$.

Perkembangan terakhir Covid-19 dari WHO, pada 3 Mei 2020, dari 215 negara, terdapat 3.356.205 kasus dan dinyatakan meninggal sebanyak 238.730 orang $^{123}$. Dari seluruh kasus di dunia, datanya terus berkembang dan terus mengalami dinamika tergantung pada kondisi setiap negara dan bagaimana kebijakannya setiap negara memiliki kebijakan masing-masing dalam menghadapinya. Hal itu juga sangat ditentukan oleh respons masyarakatnya yang begitu beragam dan besar kecil jumlah populasinya bersifat relatif. Data WHO ini merupakan salah satu pijakan sementara dalam mengamati perubahan dinamika global dalam menghadapi Covid-19 yang memberi banyak implikasi luas pada krisis sosial, ekonomi, dan keamanan.

Implikasi lainnya yang sangat urgen dalam artikel ini adalah sikap umat beragama di seluruh dunia, khususnya Islam dalam mengikuti saran WHO dan ilmuwan untuk melakukan social distancing. Mayoritas umat beragama (Kristen, Protestan, Islam, Buddha, Hindu, Yahudi, dan sejenisnya) di seluruh dunia mempercayai dan mengikuti pihak otoritas keilmuwan (sains) dan otoritas kesehatan dunia, WHO. Misalnya, umat Kristen beribadah tidak perlu di gereja, tetapi cukup di rumah. Umat Islam tidak perlu pergi sholat jumat atau pergi ke masjid terlebih dahulu, ibadah haji kemungkinan besar ditiadakan

122. WHO, "Basic protective measures against the new coronavirus", https://www.who.int/emergencies/ diseases/novel-coronavirus-2019/advice-for-public, diakses 14 April 2020; "Social Distancing, Quarantine, and Isolation", https://www.cdc.gov/coronavirus/2019-ncov/prevent-getting-sick/social-distancing.html, diakses 14 April 2020.

123. "Coronavirus disease (Covid-19) Pandemic", https://www.who.int/emergencies/diseases/novelcoronavirus-2019, diakses 4 Mei 2020. 
tahun ini ${ }^{124}$, dan sejenisnya tahun ini ditiadakan oleh pemerintah Arab Saudi. Daerah Timur Tengah umumnya menutup tempat ibadah dan melaksanakan sholat di rumah juga ${ }^{125}$. Selain itu, organisasi besar di Indonesia, Nahdlatul Ulama (NU) dan Muhammadiyah pun mendukung upaya ilmuwan dan logika sains dalam memerangi Covid-19. NU menunda Musyawarah Nasional Alim Ulama (Munas) dan Konferensi Besar (Konbes) yang semula akan digelar pada 18-19 Maret 2020 di Pondok Pesantren Al-Anwar, Rembang, Jawa Tengah. Muhammadiyah pun mengganti waktu Muktamar ke-48 (1-5 Juli 2020) di Solo, Jawa Tengah yang diputuskan 24-27 Desember 2020. Mayoritas umat Islam lebih mengutamakan fatwa yang mengutamakan kepentingan umum dibandingkan kepentingan kelompok (maslahah mursalah) demi melindungi nyawa (hifdz alhayat) dari bahaya Covid-19 (mudharat) adalah tujuan dari syariat Islam (maqasid al-sharia).

Ada pendapat dari kelompok anti-sains atau tidak peduli (ignorance) dengan sains bahwa kepercayaan terhadap sains membuat kaum beragama menjadi murtad/kafir atau ateis (disbelief) atau dalam Islam dinamakan syirik. Kasus di Amerika Serikat, konservatisme agama, khususnya kelompok republikan nasionalis-agamis dan gerakan kristen nasionalis Amerika justru berusaha mengerdilkan peran sains dalam menghadapi Covid-19. ${ }^{126}$ April 2020, di Virginia, seorang pastur tetap membuka gerejanya dan berkhotbah "...unless I'm in jail or the hospital because people are healed" (in his church). Pada akhirnya, pastur tersebut tidak ke penjara atau ke rumah sakit, tetapi dikuburkan seminggu setelah khutbahnya. ${ }^{127}$ Kasus lain, seorang pendukung kuat Presiden Amerika Serikat, Donald Trump, seorang pastur di gereja Tampa Bay, Florida yang berpengaruh tertangkap kamera mengatakan agar semua anggota jamaatnya saling bersalaman sedangkan yang tidak mau disebut 'banci'. Bagi anggotanya, gereja adalah tempat paling aman. Dia berkata dengan canda, "If you cannot be saved in church, you are in serious trouble"128.

124. Martin Chulov, "Hajj pilgrimage could be cancelled because of coronavirus", https://www.theguardian. com/world/2020/apr/01/hajj-pilgrimage-could-be-cancelled-because-of-coronavirus-islamic

125. Ben Simon, "Religion in conservative Mideast adapts to coronavirus" https://www.thejakartapost.com/ news/2020/03/24/religion-in-conservative-mideast-adapts-to-coronavirus.html, diakses 15 April 2020.

126. Katherine Stewart, "The Religious Right's Hostility to Science Is Crippling Our Coronavirus Response", https://www.nytimes.com/2020/03/27/opinion/coronavirus-trump-evangelicals.html.

127. Bil Browning, "Defiant pastor who kept church open despite coronavirus warnings dies a week later from COVID-19", https://www.lgbtqnation.com/2020/04/defiant-pastor-kept-church-open-despite-coronaviruswarnings-dies-week-later-covid-19/.

128. Alex Bollinger, "Pastor who laid hands on Trump says avoiding coronavirus is for "pansies"” https://www. Igbtqnation.com/2020/03/pastor-laid-hands-trump-says-avoiding-coronavirus-pansies/, diakses 14 April 2020. 
Menurut argumen Katherine Stewart $(2020)^{129}$, gerakan nasionalis Kristen Amerika ini bukan sekelompok orang taat beragama saja, tetapi mereka sudah masuk definisi gerakan ideologi politik yang sampai saat ini mendukung Trump; mereka adalah kelompok "conservative". Bagi mereka, Amerika Serikat adalah bangsa Kristen. Mereka anti-sains, anti-climate sciences, termasuk tidak percaya bahaya global warming. Jadi menurut Katherine, kelompok keagamaan ideologis ini justru mendukung pemerintahan Amerika Serikat untuk bertindak kontra produktif terhadap penanganan Covid-19. Trump dan kelompok conservative saling mendukung dalam melemahkan peran sains menghadapi Covid-19 demi urusan keagamaan dan ekonomi ${ }^{130}$.

Namun tidak semua kelompok conservative itu ideologis. Kasus lain yang terjadi pada Maret 2020 di Korea Selatan justru muncul dari gereja conservative yang taat. Mereka awalnya tidak peduli terhadap Covid-19 dan justru memberi harapan masuk surga, tetapi akhirnya mereka terbuka dan mau bekerja sama dengan pemerintah. Ketua sekte keagamaan Gereja Yesus Shincheonji yang mengklaim dirinya sang Messiah, Lee Man-hee akhirnya 'sujud' minta maaf terhadap bangsa Korea karena gerakannya menimbulkan penyebaran Covid-19 lebih dari separuh kasus di Korea Selatan. Hal itu terjadi setelah kuatnya gelombang protes sampai muncul petisi dari masyarakat di sekitar agar gereja tersebut ditutup. Berita awal Maret 2020 menginformasikan dari semua orang yang positif Covid-19 di Korea Selatan, sekitar 60 persennya bersumber dari kluster anggota gereja tersebut. Hal ini terjadi karena di saat pandemi, mereka masih saja melakukan aktivitas ritual tanpa mempertimbangkan peringatan social/physical distancing secara sembunyi-sembunyi dengan mobilitas anggota sekte yang tinggi. ${ }^{131}$

Kasus lain yang tak berhubungan dengan ideologi politik adalah Ijtima Jamaah Tabligh di masjid Sri Petaling, Malaysia (28 Februari-1 Maret 2020). Acara dihadiri kira-kira 16.000 orang, termasuk 1.500 orang asing. Acara ini menjadi sumber penyebaran Covid-19 terbesar di Asia Tenggara saat itu. Banyak pihak mempertanyakan pihak otoritas Malaysia, seperti diplomat Singapura yang mempertanyakan mengapa acara tersebut tetap berlangsung. Ada yang berpendapat bahwa urusan Tuhan (Allah) di Malaysia sangat penting.

129. Katherine Stewart, The power of worshippers: Inside the dangerous rise of religious nationalism, New York: Bloomsbury Publishing, 2020.

130. André Gagné, “Coronavirus: Trump and religious right rely on faith, not science", https://theconversation. com/coronavirus-trump-and-religious-right-rely-on-faith-not-science-134508, diakses 14 April 2020.

131. BBC, "Coronavirus: South Korea church leader apologises for virus spread", https://www.bbc.com/news/ world-asia-51701039, diakses 14 April 2020; Laura Bicker, "Coronavirus: South Korea sect leader to face probe over deaths", https://www.bbc.com/news/world-asia-51695649, diakses 15 April 2020. 
Dari peserta tabligh banyak yang lebih percaya Tuhan daripada dites Covid19.132 Pesertanya yang datang dari berbagai negara sulit dilacak lagi setelah acara tersebut selesai, khususnya sebagian besar peserta dari Indonesia yang berjumlah 696 orang dan telah pulang ke Indonesia. Karena sulitnya melakukan pelacakan, pemerintah menghimbau bagi para peserta untuk datang dan dites secara sukarela. ${ }^{133}$

Setelah kasus Malaysia, para Jamaah Tabligh masih juga mengadakan acara di Gowa, Sulawesi Selatan (19-22 Maret 2020) di saat Covid-19 mewabah. Dalam kondisi berbahaya, acara ini telah dihadiri sebanyak 8.223 orang. Mereka sudah berkumpul, berpelukan, dan makan bersama dalam satu nampan dengan tiga jari tangan. Dengan bangga dan gagah berani, salah satu panitia, Mustari Bahranuddin melakukan perlawanan dan berseru, "we are more afraid of God" (daripada Covid-19). ${ }^{134}$ Lanjutnya, Bahranuddin berkata, "Setiap manusia takut sakit, takut mati" dan dia juga berkata, "Tapi ada yang lebih dari fisik, yaitu jiwa." 135 Syeh Fadel, salah satu peserta berkata, "We are thousands and we are not scared of any Chinese virus". ${ }^{136}$ Akhirnya, walau terlambat, puncak kegiatan ini berhasil dibatalkan oleh Gubernur Sulawesi Selatan, Nurdin Abdullah, setelah

132. A. Ananthalakshmi, Joseph Sipalan, "How mass pilgrimage at Malaysian mosque became coronavirus hotspot", https://www.reuters.com/article/us-health-coronavirus-malaysia-mosque/how-masspilgrimage-at-malaysian-mosque-became-coronavirus-hotspot-idUSKBN2142S4 15 April 2020; "How Sri Petaling tabligh became Southeast Asia's Covid-19 hotspot", https://www.nst.com.my/news/ nation/2020/03/575560/how-sri-petaling-tabligh-became-southeast-asias-covid-19-hotspot, diakses 15 April 2020; Tashny Sukumaran "How the coronavirus spread at Malaysia's tabligh Islamic gathering", https://www.scmp.com/news/asia/southeast-asia/article/3075654/how-malaysias-sri-petaling-mosquebecame-coronavirus, diakses 15 April 2020.

133. CNN Indonesia, "696 WNI Peserta Tabligh Akbar Malaysia Diimbau Tes Corona”, https://www. cnnindonesia.com/nasional/20200314090234-20-483346/696-wni-peserta-tabligh-akbar-malaysiadiimbau-tes-corona diakses 15 April 2020; CNBC Indonesia, "Corona di Tabligh Akbar, 696 WNI Diimbau Periksakan Diri", https://www.cnbcindonesia.com/news/20200314060024-4-144839/corona-di-tablighakbar-696-wni-diimbau-periksakan-diri, diakses 15 April 2020; Antara, "Positif Corona, 17 WNI Jamaah Tabligh di India Masih Dirawat", https://nasional.tempo.co/read/1330023/positif-corona-17-wni-jamaahtabligh-di-india-masih-dirawat/full\&view=ok, diakses 15 April 2020.

134. Tom Allard dan Agustinus Beo Da Costa, "Muslim event in Indonesia stopped amid coronavirus fears", https://uk.reuters.com/article/uk-health-coronavirus-indonesia-event/muslim-event-in-indonesiastopped-amid-coronavirus-fears-idUKKBN21605S, diakses 15 April 2020; Republika, "Tanpa Izin, Jamaah Tabligh Tetap Gelar ljtima' Dunia di Gowa https://republika.co.id/berita/q7e4lx327/tanpa-izin-jamaahtabligh-tetap-gelar-ijtima-dunia-di-gowa, diakeses 15 April 2020.

135. Miranti Kencana Wirawan, "Media Asing Sorot Jemaah Tabligh Indonesia: Kami Lebih Takut pada Tuhan", https://www.kompas.com/global/read/2020/03/19/073816170/media-asing-sorot-jemaahtabligh-indonesia-kami-lebih-takut-pada-tuhan?page=all, diakses 15 April 2020.

136. Amanda Hodge, "Coronavirus: Pilgrims inoculated by faith", https://www.theaustralian.com.au/world/ coronavirus-pilgrims-inoculated-by-faith/news-story/78f1f289378a52c077cb0371ac2cbc9d, diakses 15 April 2020. 
sebelumnya panitia melakukan perlawanan terhadap pemerintah daerah dan pusat $^{137}$.

Selain itu dalam kondisi dilarang berkumpul dan berdekatan kurang dari satu meter, acara keagamaan umat Katolik pun tetap berlangsung pada 19 Maret 2020. Misa Penahbisan di Nusa Tenggara Timur pun tetap digelar dengan dalih dikurangi dari tujuh ribu menjadi seribu orang dan difasilitasi alat deteksi seperti thermogun dan hand sanitizer serta pengawasan yang ketat. Jadi dengan alasan-alasan itu, mereka tetap menyelenggarakan acara tersebut dengan hikmat dan dinikmati publik. ${ }^{138}$ Mereka berbeda pendapat dengan pemerintah propinsi dengan tetap menggelar ritual tersebut. Bupati Manggarai, Flores, Deno Kamelus pun tak berdaya menghadapi resistensi Keuskupan Ruteng Mgr Ruteng Mgr Siprianus Hormat. ${ }^{139}$

Lain halnya ritual nyepi Hindu, (24 Maret 2020) di Candi Prambanan, Klaten pun tetap dijadwalkan walaupun akhirnya hanya dibatasi sekitar dua ratus orang. Pengurus Harian Pusat Parisada Hindu Indonesia (PHDI) Jawa Tengah menyampaikan kegiatan seremonial ditiadakan sementara ritual nyepi tetap akan dijalankan. Gubernur Jawa Tengah, Ganjar Pranowo bersama Forum Kerukunan Umat Beragama (FKUB) sepakat untuk menerapkan social distancing di tempat ibadah dan tempat umum.

Selain kasus resistensi dari umat beragama di atas, umat beragama juga mempunyai keyakinan tersendiri dalam menyelesaikan masalah wabah Covid-19. Di India, atas nama tradisi yang sakral dan turun temurun, orang Hindunasionalis pendukung partai politik Prime Minister Narendra Modi beramairamai melakukan ritual minum air kencing lembu demi mencegah Covid-19.140 Lembu dipercayai merupakan makhluk suci yang bisa memberi pencegahan atau penyembuhan suatu penyakit. Salah satu dari sekitar 200 peserta peminum air kencing lembu bersama berkata, "We have been drinking cow urine for 21 years, we

137. Andi Hajramurni, "COVID-19: South Sulawesi cancels mass religious event, but not before thousands arrive on site", https://www.thejakartapost.com/news/2020/03/19/covid-19-south-sulawesi-cancels-massreligious-event-but-not-before-thousands-arrive-on-site.html, diakses 15 April 2020; Resmi Dibatalkan, Echa Panrita Lopi, "Peserta ljtima Tabligh Dunia 2020 di Gowa Akan Diisolasi”, https://makassar.terkini.id/ resmi-dibatalkan-peserta-ijtima-tabligh-dunia-2020-di-gowa-akan-diisolasi/, diakses 15 April 2020.

138. Edika Ipelona, "Diminta Ditunda Karena Virus Corona, Misa di Ruteng Tetap Berlangsung", https://www. kompas.tv/article/72090/diminta-ditunda-karena-virus-corona-misa-di-ruteng-tetap-berlangsung, diakses 15 April 2020.

139. Robertus Belarminus, "Ini Alasan Misa Penahbisan Uskup Ruteng Tak Bisa Ditunda”, https://regional. kompas.com/read/2020/03/19/12213691/ini-alasan-misa-penahbisan-uskup-ruteng-tak-bisa-ditunda, diakses 15 April 2020.

140. BBC, “Coronavirus: Does drinking tea help? https://www.bbc.com/news/world-asia-india-51910099, diakses 15 April 2020. 
also take a bath in cow dung. We have never felt the need to consume English medicine". ${ }^{141}$ Di kota Raipur, Bangladesh (18 Maret 2020) sebanyak 30.000 (10.000 versi polisi) umat muslim sholat berjamaah untuk membebaskan Bangladesh dari Covid-19. Demi keyakinan Islam, mereka menjalankan acara ini tanpa izin pemerintah dan kepolisian, toh memang biasanya tidak diperlukan izin jikalau ingin mengadakan acara sejenisnya. Mereka menunjukkan sholat yang mereka namakan "the Six Quranic Verses of Healing"142.

Kasus-kasus di atas memberikan bukti (fakta) bahwa beberapa kalangan umat beragama mempunyai pandangan yang berbeda-beda satu dengan yang lain. Kasus di atas juga memberi pandangan bahwa sampai saat ini, masih ada kelompok agama yang resisten terhadap atau tidak percaya kepada sains. Walaupun kasus ini hanyalah kelompok kecil dari umat beragama, tetapi hal yang perlu disadari adalah di setiap zaman, selalu ada kelompok kecil yang masih mempunyai dunianya sendiri. Banyak alasan dibalik fenomena tersebut, baik secara internal individu dan kelompok maupun eksternal (sistem budaya dan lingkungan).

Dalam Islam, Menurut Prof Iswandi Syahputra ${ }^{143}$, kemunculan Covid-19 memberi kemunculan pula pada dua perspektif Islam dalam menghadapi Covid-19: Pertama, perspektif Jabariah. Jika dilihat dari perspektif Jabariah, posisi SARS-CoV-2 di bawah kuasa Allah. Kita harus lebih takut pada Allah dibandingkan takut pada korona. Menurut Iswandi, argumen kaum Jabariah ini tidak masuk akal sebab Covid-19 tidak masuk akal jika dibandingkan dengan Allah SWT -Allah adalah Yang Maha Besar dan Segalanya. Pandangan Jabariah menempatkan manusia sebagai boneka milik Allah. Apapun yang dilakukan manusia adalah kehendak Allah. Manusia harus menerima apapun yang diberikan Allah. Manusia hidup dalam takdir Allah.

Sebaliknya, kedua, perspektif Qadariyah. Manusia mempunyai kehendaknya sendiri dalam menghadapi korona. Korona bukanlah takdir Allah. Oleh sebab itu, ada upaya akal dalam bentuk sains untuk menghadapi korona. Walaupun vaksinnya belum ditemukan, tetapi sementara ini sains memberi saran pada

141. DW, "Hindu group hosts cow urine drinking party to ward off coronavirus", https://www.dw.com/en/ hindu-group-hosts-cow-urine-drinking-party-to-ward-off-coronavirus/a-52773262, diakses 15 April 2020; Danish Siddiqui, "Hindu group offers cow urine in a bid to ward off coronavirus", https://www.reuters. com/article/us-health-coronavirus-india-cow-urine-pa-idUSKBN2110D5, diakses 15 April 2020.

142. BBC, "Coronavirus: Bangladesh mass prayer event prompts alarm," https://www.bbc.com/news/worldasia-51956510, diakses 15 April 2020; "Massive Bangladesh coronavirus prayer gathering sparks outcry", https://www.bangkokpost.com/world/1882015/massive-bangladesh-coronavirus-prayer-gathering-sparksoutcry

143. Iswandi Syahputra, "Ada Qadariyah dan Jabariyah dalam virus Corona”, https://republika.co.id/berita/ q7f80o385/ada-qadariyah-dan-jabariyah-dalam-virus-corona, diakses 18 April 2020. 
umat manusia untuk social distancing, cuci tangan, dan memakai masker dengan terus berusaha menemukan vaksin. Perspektif ini pada prinsipnya berkeyakinan bahwa manusia memiliki kebebasan menentukan jalan hidupnya sendiri.

Dalam rangka menengahi kedua perspektif di atas, Iswandi memberi upaya ikhtiar, sabar dan tawakkal. Baginya, korona adalah ujian dan tanda agar kita berpikir apakah kita sombong atau tidak. Baginya, korona tidak hanya perlu diatasi dengan sains, tetapi dengan akhlak. Argumen ini juga merupakan ranah agama bukan sains, karena memberi solusi yang sifatnya transcendental, bukan immanent; yang terkait dengan ritual internal diri manusia bukan rasional dan eksternal dari diri manusia.

Saya tidak mau melanjutkan polemik berkepanjangan tentang sejarah konfliktual perspektif teologi dalam Islam: Jabariah vs. Qadariah, akal vs. wahyu, Bayani vs. Burhani, dan sejenisnya ${ }^{144}$ dalam menghadapi kompleksitas problem kehidupan (duniawi). Perdebatan ini memang memberikan cakrawala luas bagi umat Islam bahwa sebelum modernitas Eropa lahir, Islam sudah 'modern' terlebih dahulu, karena penggunaan akal dan sains memang telah dikembangkan di zaman abad keemasan Islam di Andalusia, khususnya dalam menanggulangi wabah penyakit ${ }^{145}$. Saat itu umat Islam tidak hanya pasif pasrah, tetapi mengembangkan ilmu pengetahuan tentang wabah penyakit. ${ }^{146}$ Singkat cerita, sains dalam Islam sudah ada sehingga potensi-potensi yang sudah ada seharusnya terus dikembangkan sampai saat ini. Namun sains dalam Islam justru dikembangkan oleh para ilmuwan Barat di abad modern. ${ }^{147}$ Sebelum masuk ke dalam pembahasan Islam dan sains, saya tertarik membahas terlebih dahulu modernitas dalam konteks rezim sekularisme/agenda politik modernsekuler, yakni secara sederhana mengedepankan pemisahan urusan duniawi seperti sains dan politik dengan agama.

Awal modernitas di masa Renaissance lalu Enlightenment, agenda politik sekuler memberi kesempatan luas bagi sains dalam menentukan kehidupan duniawi umat manusia (anthropocentrism). Saya berargumen bahwa agenda kaum beragama yang ignorance terhadap agenda sains dalam menangani Covid-19 justru membenarkan agenda politik modern-sekuler. Kaum beragama

144. John L. Esposito, The Oxford dictionary of Islam, UK: Oxford University, 2003.

145. Asrudin Azwar, Musa Maliki, “Covid-19, Agama, Dan Sains”, https://geotimes.co.id/kolom/covid-19agama-dan-sains/, diakses 30 April 2020.

146. Zacky Khairul Umam, "Korona, Antara Sains dan Agama", Kompas, 10 Maret 2020; Lihat juga lebih detail dan mendalam penelitian Justin K. Stearns yang menjadi dasar utama dari argumen sejarah Zacky dalam artikelnya, Justin K. Stearns, Infectious ideas: contagion in premodern Islamic and Christian thought in the Western Mediterranean, USA: The Johns Hopkins University Press, 2011.

147. Ibid. 
mengkonstruksikan discourse-nya dalam menghadapi kompleksitas problem kehidupan (duniawi), khususnya problem Covid-19 dengan cara-cara 'agama' (reduksionis). Dalam hal ini, mereka sudah masuk ke dalam perangkap definisi "agama" dalam discourse kaum sekuler.

Definisi agama menurut kaum sekuler adalah aktivitas yang bermuatan transcendental bukan immanent, seperti ritual (doa-doa), takhayul (superstitious), doktriner, tampilan-tampilan simbol yang mengacu pada sumber-sumber scriptural dengan pembacaan (metodologi) literal-tekstual bukan berdasarkan pada metodologi berpikir ilmiah dan filsafat. Hal ini membenarkan argumen beberapa ilmuwan (sosial) sekuler terhadap kaum beragama sebagaimana disebutkan di atas. Lebih jauh lagi, mereka memunculkan berbagai macam istilah-istilah kaum beragama tersebut demi mendefinisikannya lebih mendalam dan kontekstual dengan maksud tetap dapat mengontrol (secara keilmuwan) pola discourse dan praktik diskursifnya.

\section{Agenda Politik Modern-Sekuler}

Agenda politik modern-sekuler adalah proyek perkembangan institusi baru di Reformasi Eropa berdasarkan pada kekuasaan non-agama yang berdoktrin sekularisme sebagai solusi dari perang agama selama 30 tahun (Thirteen Years War). Sekularisme adalah doktrin ideologi politik dalam sebuah institusi baru non-agama yang bernama "sistem kedaulatan negara-bangsa" yang lahir 1648. Sistem negara-bangsa ini berusaha membatasi agama agar perang agama tidak terjadi lagi. Sejak peristiwa politik ini, agama didefinisikan ulang. Saya merujuk pada penelitian Elizabeth Shakman Hurd:

"According to conventional accounts, religion was "privatized" in 1648 at the Peace of Westphalia as a solution to sectarian violence in Europe. Yet this claim to delimit the terms and boundaries of modern politics by defining religion as its private counterpart is a politicized move that must be historically contextualized. Secularism is a form of authorized knowledge that creates and perpetuates particular claims about the limits of modern politics; claims which have become established settlements operating below the threshold of public international discourse. These settlements lie at the core of modern assumptions about and practices of state sovereignty". ${ }^{148}$

Di sini saya juga ingin mengutip peneliti pendukung ide sekularisme, Charles Taylor: "It is generally agreed that modern democracies have to be "secular" ...involve some kind of separation of church and state... The pluralism of society requires that there

148. Elizabeth Shakman Hurd, "Secularism and International Relations Theory", dalam Religion and International Relations Theory, diedit Jack Syder, USA: Columbia University Press, 2011, hlm. 85. 
be some kind of neutrality"149. Bagi Taylor, gagasan tentang sekularisme adalah satu-satunya cara agar dunia harmonis dari konflik agama - berkaca pada pengalaman buruk Eropa. Dalam rezim sekularisme, agama tetap diberi ruang, tetapi tetap dieksklusi dari ruang publik agar ruang publik tersebut steril dari agama. Dalam rezim ini, ruang publik adalah ruang non-agama (sains, politik, dan sosial) termasuk dimensi moralnya pun harus berada di bawah negarabangsa. ${ }^{150}$

Kelahiran rezim sekularisme ini tidak serta merta melenyapkan eksistensi discourse agama yang saat itu dikuasai Holy Roman Empire bahkan sampai sekarang. Runtuhnya kekuasan mutlak tunggal Holy Roman Empire bergeser kepada sistem Westphalia yang bersifat sekuleristik membuat eksistensi agama (Kristen) secara konstitutif dan paralel tetap berlanjut. Keduanya hidup dalam dunianya masing-masing, yakni agama secara esensial di dalam dunianya dan politik dalam dunianya. ${ }^{151}$ Ilustrasi ini adalah gambaran umum dari sejarah awal sekularisme. Saya tidak akan berpanjang lebar membahas teori dan aplikasi sekularisme di tiap negeri yang memang secara relatif berbeda-beda ${ }^{152}$.

Saya ingin mengingatkan kembali argumen utama artikel ini bahwa agama dihadirkan dalam rezim sekuler dalam kerangka berpikir sekuler demi menjadi 'alat stempel' rezim sekuler. Rezim ini terdiri dari sistem negara-bangsa yang plural, tetapi dalam sistem politik yang kurang lebih idealnya menurut Jocelyn Maclure dan Charles Taylor sistem "demokrasi liberal" dengan karakteristik di setiap negara secara relatif beragam ${ }^{153}$.

Sebelum Abad Pencerahan awal modern-sekuler, terminologi "agama” tidak populer. Di Eropa, terminologi "kepercayaan" (faith) dan "tradisi" biasa dipakai dalam discourse mereka. ${ }^{154}$ Oleh sebab itu, terminologi "agama" sendiri pun dalam argumen saya sejak awal sudah merupakan konstruksi para ilmuwan Barat sekuler. Umat beragama di dunia berusaha dikendalikan melalui discourse

149. Charles Taylor, "Why We Need a Radical Redefinition of Secularism", dalam The power of religion in the public sphere, diedit Eduardo Mendieta and Jonathan VanAntwerpen, USA: Columbia University Press, 2011, hlm.34.

150. Charles Taylor, "Western secularity", dalam Rethinking secularism, diedit oleh Craig Calhoun, Mark Juergensmeyer, dan Jonathan VanAntwerpen UK: Oxford University, 2011, hlm. 34.

151. Elizabeth Shakman Hurd, The Politics of Secularism in International Relations, USA: Princeton University Press, 2008.

152. Jocelyn Maclure, "Towards a Political Theory of Secularism" dalam The sources of secularism: Enlightenment and Beyond, diedit oleh A. Tomaszewska \& H. Hämäläinen, Switzerland: Palgrave Macmillan, 2007; Jakob De Roover, Europe, India, and the limits of secularism, Oxford: Oxford University Press, 2015.

153. Jocelyn Maclure and Charles Taylor, Secularism and freedom of conscience, diterjemahkan Jane Marie Todd, USA: Harvard University Press, 2011.

154. Craig Calhoun, Mark Juergensmeyer, dan Jonathan VanAntwerpen, "Introduction”, op.cit., hlm. 7. 
(definisi/di-frame) sekuler sadar atau tidak sadar tak terkecuali, termasuk semua kelompok Islam (banyak juga kelompok agama lainnya yang dalam keterbatasannya tak dibahas di sini) yang lahir sejak abad Pencerahan sampai abad ke-21 sekarang seperti kelompok jamaah tabligh, HTI, islamis, fundamentalis, populis Islam sampai dengan kelompok yang paling ekstrem seperti al-Qaeda, Jamaah Islamiyah, dan sejenisnya. Mereka berpikir dan beraktivitas mengambil sumber realitas dari modernitas. Mustahil bagi kaum beragama di abad sekuler Barat berpikir di luar realitas sekuler.

Dalam hal ini, sekularisme sebenarnya konsep yang kompleks dan ambigu, sebab sekularisme tetap secara tidak langsung memelihara agama dalam batasannya demi tetap menghadirkan rezim sekularisme sendiri. Hal ini juga sesuai dengan penelitian Eisenstadt yang menggambarkan peradaban modern Barat yang menampilkan perseteruan antara pihak yang sekuler dan yang agamis dan antara yang tradisional dan yang modern. Modern-sekuler pun menyebar ke seluruh dunia sekarang ini dengan Amerika Serikat sebagai pusatnya bersama dengan keberlanjutan konflik antara yang sekuler dan yang agamis dalam gambaran besar peradaban modern sekuler yang dominan ${ }^{155}$.

Di sini agenda awal modernitas terwujud, yakni 'mengandangkan' agama di dalam 'agama' itu sendiri dan 'mengandangkan' sains demi sains sendiri dalam kubu/kelompok modern-sekuler. Hal inilah yang mereduksi pemahaman agama, dalam hal ini Islam, terhadap bagaimana sikap umat Islam menghadapi Covid-19. Sikap umat Islam terhadap bahaya Covid-19 justru mengandangkan Islam ke dalam praktik-praktik ritual dan dalih-dalih tekstual. Di sisi lainnya, agenda politik modern-sekuler justru memanfaatkan sains untuk menjalankan industrialisasi dalam sistem kapitalisme global.

Dalam peradaban modern-sekuler, agama dan sains justru menjadi counterproductive. Reduksi agama ke wilayah ritual dan mutlak (qath'i) justru menjustifikasi pemahaman sekuleristik bahwa agama hanya berurusan dengan yang transcendental dan bukan immanent. Semua penyelesaian kehidupan dengan jalur agama akhirnya menggunakan discourse transcendental atau teologis sehingga belum tentu kontekstual dan fleksibel terhadap kehidupan kekinian. Problem yang lebih luasnya adalah solusi semacam ini dipaksakan di ruang publik sebagai sesuatu yang sifatnya berdosa atau tidak dan urusan masuk surga atau neraka.

155. Samuel N. Eisenstadt, "Multiple modernities". Daedalus, 129(1), 2000, hlm. 1-29; Samuel N. Eisenstadt, (2000), "The Reconstruction of religious arenas in the framework of multiple modernities, Millennium: Journal of International Studies, 29(3), 2000, hlm. 591-611. 
Sebaliknya, solusi sains dewasa ini juga justru secara arogan tidak lagi mementingkan makna ritual dan interpretasi scriptural. Seolah-olah yang transcendental pun tidak penting dalam menyelesaikan urusan dunia, khususnya Covid-19. Para ilmuwan fokus pada urusan proses saintisme tanpa disertai peran spiritualisme dan pentingnya makna-makna suci (sacred) keberagamaan. Problemnya hal ini beredar di ruang publik sebagai suatu sikap penghinaan, pelecehan, dan penentangan atas kaum beragama yang sesungguhnya dalam proses memaknai diri mereka dan komunitas mereka dalam menghadapi wabah Covid-19. Krisis modernitas yang mengeringkan makna hidup manusia modern (manusia ilmiah) sesungguhnya menjadikan peluang bagi kaum beragama untuk kembali ke arena dialektika, walaupun tidak secara literal kaum beragama menang atas kamu saintis-sekuler. Tesis telah diteliti oleh para ilmuwan sosial dan humaniora tentang 'kebangkitan' kaum beragama di era post-secular. Menurut Dustin J. Byrd ${ }^{156}$, era post-secular sebagai berikut:

"Most dialectically, it appears that the very coordinates of secularity have produced the necessary conditions for religions' continual presence - and/or rejuvenation - in society. In other words, secularity has produced a new form of religiosity: one that has become immune to secularity's attacks, or at least has found the capacity within itself to deter secularity's aggressively corrosive nature - a post-secular form of religion. This is not a world in which religion has triumphed over secularity, as could be misunderstood by reading "post" as being simply "after" in terms of time, but one where religion remains a continual and persistent presence within the increasingly secular world. Indeed, like an elastic band that is stretched at both ends, the more secular the contemporary world becomes, the more it creates the conditions for this new post-secular form of religion. The dialectic within secularity is such: as secularity expands further into the lifeworld, it unintentionally produces the conditions which are filled by religion; as it alienates and disenchants more people, the more they turn to religion to fulfill their longing for transcendence; the more atheistic and meaningless the modern world becomes, the more it simultaneously calls for the messianic, i.e. the return to religion as a complete and total way-of-being."

Lebih lanjut, Dustin memaparkan bahwa sains dan teknologi membuat kebenaran tentang agama menjadi hancur. Hal ini membuat agama menjadi tidak signifikan dalam kehidupan. Namun agama justru menjawab pertanyaanpertanyaan tentang makna hidup manusia di era post-secular:

"Science, technology, and autonomous reason all contributed to the destruction of the veritas of religious claims, and because of this the truth-element within religion has become superfluous. Despite this, secularity, as Habermas has

156. Dustin J. Byrd, Islam in a post-secular society: religion, secularity, and the antagonism of recalcitrant faith, Boston: Brill, 2019, hlm. 9-10. 
articulated, has failed to adequately address those existential questions that religion once answered and as such leaves unattended an open flank by which religion either stubbornly remains with humanity, or returns after secularity's deficiency is made abundantly clear" ${ }^{157}$.

\section{Sains dan Islam From Within}

Agenda politik modern-sekuler ternyata tidak sampai pada level menghapus sepenuhnya kaum beragama. Namun hal ini tidak berarti muncul kebangkitan agama yang sesungguhnya. Keberadaan kaum beragama yang tidak peduli terhadap bahaya wabah Covid-19 justru semacam kebangkitan Islam semu. Kebangkitan ini justru menjustifikasi prinsip sekularisme, yakni agama untuk agama dan sains untuk sains dan duniawi yang kemudian diterjemahkan menjadi kaum beragama tidak peduli pada Covid-19. Misalnya awal Ramadan ini terdapat banyak sekali kasus di antaranya di Aceh ${ }^{158}$, Bogor ${ }^{159}$, Bekasi ${ }^{160}$, Lombok $^{161}$, Parepare (kenekatan memanjat pagar masjid) ${ }^{162}$, Ciamis ${ }^{163}$, Bangka Belitung dan Tegal ${ }^{164}$, bahkan terdapat kasus di Jambi yang sudah positif Covid-19 tetap menjadi imam masjid ${ }^{165}$. Kasus-kasus tersebut hanyalah beberapa saja yang memiliki level eksistensi, partisi ruang dan waktunya sendiri dalam menghadapi ancaman modernitas, khususnya Covid-19. Sementara itu, ormas Islam terbesar

157. Ibid., hlm, 144.

158. "Virus corona: Salat tarawih berjemaah dan hukuman cambuk di Aceh tetap berlangsung, 'transmisi lokal hanya masalah waktu'," https://www.bbc.com/indonesia/indonesia-52406833; "Pandemi Covid-19, Warga Aceh Tetap Gelar Salat Tarawih Berjemaah di Masjid", https://www.liputan6.com/regional/read/4236145/ pandemi-covid-19-warga-aceh-tetap-gelar-salat-tarawih-berjemaah-di-masjid\#, diakses pada 26 April 2020.

159. Moch. Fiqih Prawira Adjie, "Indonesian Muslims hold congregational Ramadan prayers despite COVID-19 warnings", https://www.thejakartapost.com/news/2020/04/26/indonesian-muslims-hold-congregationalramadan-prayers-despite-covid-19-warnings.html.

160. Tri Subarkah, "Inilah Sejumlah Alasan Warga Tetap Tarawih Saat Pendemik Covid-19", https://mediaindonesia.com/read/detail/307362-inilah-sejumlah-alasan-warga-tetap-tarawih-saatpendemik-covid-19, diakses 26 April 2020.

161. Idham Khalid, "Cegah Penyebaran Covid-19, Tarawih di Daerah Ini Jaga Jarak 1 Meter, Diberi Tanda Silang", https://regional.kompas.com/read/2020/04/23/22035021/cegah-penyebaran-covid-19-tarawihdi-daerah-ini-jaga-jarak-1-meter-diberi, diakses pada 26 April 2020.

162. Rachmawati, "Fakta Warga Nekat Panjat Pagar Masjid untuk Berjemaah, Diminta Pulang untuk Tarawih di Rumah", https://regional.kompas.com/read/2020/04/26/15500001/fakta-warga-nekat-panjat-pagarmasjid-untuk-berjemaah-diminta-pulang-untuk; Hasrul Nawir, "Masjid di Parepare Sulsel Tetap Gelar Salat Jumat di Tengah Pandemi Corona", https://news.detik.com/berita/d-4972340/masjid-di-parepare-sulseltetap-gelar-salat-jumat-di-tengah-pandemi-corona, diakses 26 April 2020.

163. Dadang Hermansyah, "Sejumlah Masjid di Ciamis Gelar Tarawih di Tengah Pandemi Corona", https://news. detik.com/berita-jawa-barat/d-4988914/sejumlah-masjid-di-ciamis-gelar-tarawih-di-tengah-pandemicorona, diakses 26 April 2020.

164. Reny Mardika, “Warga Masih Gelar Tarawih di Masjid Dengan Protokol Covid-19,” https://www.kompas.tv/ article/77775/warga-masih-gelar-tarawih-di-masjid-dengan-protokol-covid-19, diakses 26 April 2020.

165. "Rapid Test Positif, Warga Jambi Masih Jadi Imam di Masjid," https://www.cnnindonesia.com/ nasional/20200426024720-20-497316/rapid-test-positif-warga-jambi-masih-jadi-imam-di-masjid; “Positif COVID-19, 1 Warga Jambi Masih Aktif Jadi Imam Salat di Masjid", https://www.idntimes.com/news/ indonesia/m-ramond/positif-covid-19-1-warga-jambi-masih-aktif-jadi-imam-salat-di-masjid, diakses 26 April 2020. 
di tanah air, Muhammadiyah ${ }^{166}$ dan $\mathrm{NU}^{167}$ memiliki eksistensi, partisi ruang dan waktunya sendiri yang berbeda yang diungkapkan dalam metodologi fikih (sains Islam). Demikian pula para ahli tafsir, Imam Besar Masjid Istiqlal ${ }^{168}$ dan MUI $^{169}$ yang melarang umat Islam datang ke masjid demi menghindari, saling melukai satu sama lain dari infectious disease. Metodologi kaum beragama yang tidak peduli pada himbauan sains atas bahaya Covid-19 justru membenarkan logika kaum sekuler atas agama -reduksionisme agama di wilayah ritual, pikiran dogmatik, tindakan fanatik, dan kepercayaan superstitious (metaphysical). Dengan kata lain, kasus-kasus kaum beragama yang ignore terhadap bahaya wabah Covid-19 tersebut justru mempunyai logika yang sama dengan discourse kaum modern-sekuler, tetapi dengan posisi yang berseberangan. Agenda politik modern-sekuler justru terlegitimasi dengan eksistensi kaum beragama yang secara konstitutif berlanjut terus secara dialektis bersama sekularisme. Logika kaum modern-sekuler justru benar adanya ketika kaum beragama melakukan praktik-praktik diskursif yang ritualistik dan irasional seperti kasus-kasus di atas.

Padahal dalam ajaran Islam sama sekali tidak mengandung pandangan politik modern-sekuleristik semacam di atas. Dalam Islam, hal yang sifatnya transcendental dan immanent tidak dibedakan dan dipisahkan. Yang lebih utama daripada itu adalah menempatkan cara berpikir pada level, dimensi, dan tempatnya sehingga hal yang sifatnya transcendental semacam teologi tidak dimasuk-masukkan ke dalam praktek-praktek non-transcendental teologis, tetapi immanent, seperti sosiologis, kultural, dan sejenisnya. Dari hal ini, Islam dan sains keduanya saling menguatkan, bukan saling menegasikan.

166. "Haedar Ingatkan Masyarakat untuk \#Ramadandirumah", http://m.muhammadiyah.or.id/id/news-18881detail-haedar-ingatkan-masyarakat-untuk-ramadandirumah.html?fbclid=IwAROKmZTq8sS-snTK26HbyC6O_ ZFntWCjQOfEveJIXkHSxtn4bY7FGJFcxrM; "Muhammadiyah Imbau Tarawih di Rumah: Kenapa Ngotot di Masjid?" https://www.cnnindonesia.com/nasional/20200422090547-20-495949/muhammadiyah-imbautarawih-di-rumah-kenapa-ngotot-di-masjid, diakses 26 April 2020.

167. Abdullah Alawi, "Darurat Covid-19, PBNU Imbau Masyarakat Shalat Tarawih di Rumah", https://www. nu.or.id/post/read/118670/darurat-covid-19--pbnu-imbau-masyarakat-shalat-tarawih-di-rumah, diakses 26 April 2020.

168. Faried F. Saenong, dkk, Fikih Pandemi: Beribadah di Tengah Wabah, Jakarta: NUO Publishing, 2020.

169. "Fatwa MUI No. 14 tahun 2020", https://mui.or.id/wp-content/uploads/2020/03/Fatwa-tentangPenyelanggaran-Ibadah-Dalam-siatuasi-Wabah-COVID-19.pdf, diakses 26 April 2020. Dalam hal ini perlu digarisbawahi dan menjadi catatan bahwa dalam fatwa MUI, saya berpandangan fatwa MUI masih tidak jelas dan masih pilih-pilih memberi keputusan halal atau haram dalam kondisi Covid-19. Lihat "MUI: Zona Hijau Corona Boleh Gelar Tarawih dengan Catatan", https://www.cnnindonesia.com/nasional/20200422163717-20-496197/mui-zona-hijau-corona-bolehgelar-tarawih-dengan-catatan dan "MUI: Pelaksanaan Tarawih Menyesuaikan Kondisi di Daerah", https://republika.co.id/berita/q96mz0327/mui-pelaksanaan-tarawih-menyesuaikan-kondisi-di-daerah. Bandingkan dengan larangan MUI yang lebih jelas di Muhammad IIman Nafi'an, "Ungkit Kisah Nabi, MUI Minta Warga Salat Tarawih di Rumah"

https://news.detik.com/berita/d-4988807/ungkit-kisah-nabi-mui-minta-warga-salat-tarawih-di-rumah, diakses 29 April 2020. 
Banyak penelitian yang menganalisa bahwa sains dan Islam adalah from within, yakni tidak dipisahkan, tetapi level, dimensi, dan tempatnya berada pada presisinya masing-masing. Diantaranya, karya Sayyed Hossein Nasr ${ }^{170}$ yang menjelaskan sains dalam perspektif Islam adalah pandangan hidup yang terdiri dari dimensi spiritual dan material, yang profound dan yang sacred, yang transcendental dengan yang immanent. Pandangan ini juga relevan dengan doa 'sapu jagat' yang bersumber dari surat al Baqarah, 201: Rabbana atina fid-dunya hasanatan wa fil 'akhirati hasanatan waqina 'adhaban-nar (Ya Tuhan kami, berilah kami kebaikan di dunia dan kebaikan di akhirat dan peliharalah kami dari siksa neraka). Ayat ini juga bermuatan duniawi (secular/immanent/material) dan akhirat (transcendental/spiritual). Hal yang sifatnya transcendental justru menopang spiritualisme dan mengarahkan hidup duniawi yang jelas.

Sayyed Hossein Nasr mengkritik sains Barat yang merendahkan peran spiritualisme dan meninggikan derajat rasionalisme-materialisme dalam sains positivisme modern:

"In a world such as the one in which we live today where philosophy is reduced to rationalism or more and more irrationalism and in which not only esoterism but religion itself is either denied or marginalized, the interpretation given above of the founders of Western philosophy will be rejected in many circles, and the nexus between philosophy and prophecy in general and philosophy, poetry and esoterism in particular will be dismissed or considered as being of little consequence" ${ }^{171}$.

Menurut Nasr, sejak abad pertengahan, ilmuwan Islam membingkai sains Islam dalam istilah "falsafah" dan "hikmah". Dengan kata lain, ilmuwan-ilmuwan Islam belajar secara terintegrasi dari berbagai macam ilmu dalam wadah besar filsafah dan hikmah. Oleh sebab itu, para ilmuwan Islam tidak hanya pandai dalam hal filsafat, logika, matematika atau kedokteran saja, tetapi spiritualisme dan transcendental. Mereka bertujuan untuk mencari terus kebenaran yang Allah berikan dalam wujud tanda-tanda alam. Awal dari filsafat adalah adanya kecintaan seseorang pada ilmu pengetahuan atau pencarian kebenaran. Di sinilah seorang Muslim didefinisikan sebagai tidak hanya bersumber dari nilai-nilai ke-Tuhan-an (transcendental) dan spiritualisme, tetapi atas petunjuk Allah lah para ilmuwan Islam terus menerus mengobservasi realitas (immanent) demi mencari kebenaran, bukan pembenaran. Ilmuwan Islam di abad kegemilangannya menjadikan spiritualisme sebagai dasar dari sikap keilmuan

170. Sayyed Hossein Nasr, Islamic philosophy from its origin to the present: Philosophy in the land of prophecy, USA: State University of New York Press, 2006.

171. Ibid., hlm. 5. 
mereka. Asketisme atau kezuhudan adalah salah satu karakter ilmuwan Islam abad itu. Mereka biasa dipanggil "philosopher-scientist"172. Al-Tabbari (838-870), Al-Razi (Rhazes, 864-930), Al-Zahrawi (Albucasis, 936-1013), Al-Biruni (9731050), Ibn Sina (Avicenna, 980-1037), Ibn al-Haitham (960-1040), Ibn alNafis (1213-1288), Ibn Khaldun (1332-1395), Ibn al-Baitar (1197-1248), and Ibn Zuhr (Avenzoar, 1091-1161) adalah para ilmuwan Islam. ${ }^{173}$ Para ilmuwan ini tidak hanya mensintesakan tradisi kedokteran (melalui metode sains dan eksperimentasi) dari Yunani, tetapi juga dari Persia, India, dan Cina. Karya-karya mereka menyebar ke seluruh sekolah kedokteran Eropa pada abad pencerahan sampai sekarang. Mereka memberikan kontribusi besar bagi dunia kedokteran, khususnya bagi Ibn Sina dan al Razi yang menuntun pada pengenalan metode "karantina" (40 hari):

"They are regarded as among the greatest medical authorities of the ancient world and the medieval world, physicians whose textbooks were used in European universities up to the sixteenth century. These Arab and Muslim scholars were among the first to make accurate diagnoses of plague, diphtheria, diabetes, gout, cancer, leprosy, rabies, and epilepsy. Avicenna's and Rhazes's works on infectious diseases led to the introduction of quarantine as a means of limiting the spread of these diseases" ${ }^{174}$

Sains Islam berbeda dengan sains yang berkembang di Barat sejak kelahiran sekularisme. Sains Islam adalah pelayan Allah dan khalifah Allah, sedangkan sains Barat adalah modern consumer ${ }^{175}$ atau mudahnya pengejar materialisme tanpa henti. Poin penting konteks sains Islam adalah ilmu pengetahuan Islam yang didefinisikan sebagai ilmu apapun, tidak hanya dalam definisi ModernBarat yakni ilmu-ilmu alam seperti teknik, fisika, biologi, matematika, dan kimia, karena semuanya sakral dalam level dimensi tertentu. Dalam Islam, sains adalah filsafat dan filsafat sendiri adalah hikmah yang meliputi kosmos (alam semesta). ${ }^{176}$ Sains Barat berbeda dengan sains Islam yang memiliki fondasi etika ke-Tuhan-an secara inheren dari berbagai macam pengalaman keberagamaan mereka. Ilmuwan Islam adalah seorang spiritualis, filosofis, dan ahli al-Quran. Misalnya penemu metode pertama "quarantine" Ibn Sina selain bergelar "Shaikh al-Ra'is, yakni pemimpin bagi orang-orang bijak, beliau juga penghafal

172. Ibid., hlm. 45.

173. Bashar Saad, Omar Said, Greco-Arab and Islamic herbal medicine: traditional system, ethics, safety, efficacy, and regulatory issues, USA: John Wiley \& Sons, Inc, hlm. 8.

174. Ibid. hlm. 73. Lihat juga Muhammad Subarkah, "Ide Karantina Dan Bapak Kedokteran Moderen, Ibnu Sina", https://republika.co.id/berita/q90sno385/ide-karantina-dan-bapak-kedokteran-moderen-ibnu-sina, diakses 30 April 2020.

175. Sayyed Hossein Nasr, Traditional Islam in the modern world, USA \& UK: Kegan Paul International, 1994, hlm. 18-19.

176. Sayyed Hossein Nasr, op.cit. 2006, hlm. 45. 
al-Quran saat berumur 10 tahun. Selain Ibn Sina, al-Razi juga seorang yang sangat filosofis dan spiritual. Menurut al-Razi, penyakit mempunyai sebab-sebab fisik, bukan hukuman Tuhan. Al-Razi saat itu menolak superstitious dan dogma yang tidak berdasarkan pada realitas fisik yang dapat diobservasi. Sebagai seorang filsuf dan spiritualis, Al-Razi (belajar filsafat dari ibn Rabban al-Tabari) berpandangan bahwa sains membawa umat manusia kepada pencerahan: "I prayed to God to direct and lead me to the truth...to seek and find the truth and bring light out of darkness. ${ }^{177}$

Sebaliknya dalam dunia modern yang bersistem kapitalistik, sains Barat justru menuntun umat manusia untuk ignore atas (kehadiran) Tuhan dengan tanpa mencari kebenaran-Nya (tanda-tanda kebesaran-Nya), tetapi melayani konsumerisme dan proses ini justru mengantarkan pada kekosongan hidup, keterasingan, dan kehancuran bumi. ${ }^{178}$

Hal itu berbeda dengan beberapa kaum beragama yang ignore terhadap Covid-19 dalam level eksistensinya, mereka mempergunakan agamanya sebagai 'alat defensif atau proteksi diri' dari desakan (tekanan) sistem kapitalisme. Mereka menciptakan narasi mazhabnya di alam modernitas untuk mengisi kekosongan makna hidupnya, menjelaskan hubungan mereka dengan dunia spiritual dan juga menuntun bagaimana mereka hidup. Mereka mempunyai pandangan dunia kemasukakalannya sendiri. ${ }^{179}$ Narasi yang diciptakan dalam sistem discourse kaum beragama yang ignore atas Covid-19 ini memberi kedamaian, kenyamanan, dan kebesaran terhadap mereka, tetapi belum menyelesaikan keberadaan Covid-19. Sains modern mungkin bisa menyembuhkan penyakit Covid-19, tetapi sains modern tidak bisa menyelesaikan masalah tekanan hidup dalam menghadapi kegelisahan hidup dalam kesehariannya, keputusasaan hidup, kekosongan eksistensi diri, dan tragedi yang menimpanya. ${ }^{180}$

Dalam sains Islam, keduanya selaras dan secara konsisten segaris. Jika kembali ke al-Quran yang tekstual (ayat-ayat/tanda-tanda Qauliyah), maka kita diajak merenung, berefleksi bahwa kosmos alam semesta adalah realitas (wujud) Tuhan. Ayat-ayat (tanda-tanda) alam semesta (Kauniyah) adalah refleksi dari keberadaan Tuhan Yang Maha Penyayang, Pengasih dan seterusnya. Semesta adalah pemberian dari Pengasih dan Penyayang agar makhluk semesta,

\footnotetext{
177. Bashar Saad, Omar Said op.cit., hlm. 26.

178. Manuel Arias-Maldonado, Environment and Society Socionatural Relations in the Anthropocene, USA \& UK: Springer, 2015.

179. Karen Armstrong, A Short History of Myth, UK: Canongate Books Ltd, 2005.

180. Karen Armstrong, The Lost Art of Scripture, UK: the Bodley Head, 2019, hlm. 9.
} 
khususnya manusia mengenal-Nya. Dalam penelitian Sayyed Hossein Nasr, seni dan sains yang wujudnya material adalah perwujudan (eksistensi) Allah yang transcendental. Seni dan sains adalah manifestasi Allah yang Divine Unity (Tauhid):

"The arts and sciences in Islam are based on the idea of unity, which is the heart of the Muslim revelation. Just as all genuine Islamic art, whether it be the Alhambra or the Paris Mosque, provides the plastic forms through which one can contemplate the Divine Unity manifesting itself in multiplicity, so do all the sciences that can properly be called Islamic reveal the unity of Nature. One might say that the aim of all the Islamic sciences-and, more generally speaking, of al1 -the medieval and ancient cosmological sciences -is to show the unity and interrelatedness of all that exists, so that, in contemplating the unity of the cosmos, man may be led to the unity of the Divine Principle, of which the unity of Nature is the image". ${ }^{181}$

Penelitian Nasr di atas dikuatkan oleh argumen Tariq Ramadan yang menyatakan bahwa alam semesta adalah (sign/ayat) tanda-tanda dari keberadaan Allah: "From the outset, the revealed text establishes a link between the written Revelation, knowledge, and the surrounding Universe, as three dimensions testifying to God's presence ${ }^{182}$. Bagi Ramadan, alam semesta ('yang material' dalam konsepsi sains Barat) adalah satu kesatuan dimensi keberadaan Allah selain dari pada wahyu dan (ilmu) pengetahuan. Hal ini membuat alam semesta tidak hanya material saja tetapi sesuatu yang sakral dan dengan demikian bermakna bagi relasi antara manusia, alam, dan Tuhan. Argumen Ramadan dikuatkan oleh Nasr yang mengatakan alam semesta (yang belum diformat menjadi seni dan sains) adalah juga tandatanda wujud Allah:

"Viewed as a text, Nature is a fabric of symbols, which must be read according to their meaning. The Quran is the counterpart of that text in human words; its verses are called ayat ("signs"), just as are the phenomena of Nature. Both Nature and the Quran speak forth the presence and the worship of God". ${ }^{183}$

Tariq Ramadan menekankan arti "ayat/ayah" sebagai "tanda-tanda” (sign), bukan "verses" yang diambil dari discourse Barat pencerahan (politik sekuler). Sebagai tanda-tanda Allah, alam semesta ini dimaknai sebagai duplikat atau cerminan dari al Quran dan keduanya adalah cerminan dari pemilik sumber kehidupan, yakni wujud Allah (the presence of Allah):

181. Sayyed Hossein Nasr, Science and civilization in Islam, Chicago: ABC International Group Inc, 2001, hlm. 21-22.

182. Tariq Ramadan dalam menjelaskan alam semsas sebagai perwujudan/kehadiran Allah merujuk pada sumber al-Quran 64:1; 81:15-20; 87:1-5. Lihat Tariq Ramadan, Radical reform: Islamic ethics and liberation, Oxford: Oxford University Press, 2009, hlm. 87.

183. Sayyed Hossein Nasr, opt.cit., h/m. 24. 
"The Heavens and the Earth, night and day, space and time, testify to the presence and infinite generosity of the One who has laid out the Universe like an open book pervaded with "signs" offered to people's minds and hearts. The notion of "signs" (âyât, sing. ayah) is essential and from the very beginning it establishes a corresponsdence between orders. What has been translated as "verses" in European languages-on the basis of the "verses" in Biblical versification -has quite a different meaning in Arabic. The exact translation, which is most significant here, is "sign," which means that the revealed text is made up of "signs" exactly as the surrounding Creation is a Universe of signs that must be grasped, understood, and interpreted. Signs tell of meaning ... and the signs in the Universe therefore reveal that the latter is fraught with meaning. One finds this even in Abû Hâmid al-Ghazâlî̀s profound reflections about the "outspread book" (al-kitâb al-manshûr), the Book of the Universe, which is the theological as well as physical mirror of the Quran, the "written book" (al-kitâb al-mastûr). This theme was common in early renaissance European literature and gradually changed the outlook of the world, which was seen as a space to be deciphered, interpreted, and understood: a horizon open to reason, learning, and science". ${ }^{184}$

Dari penelitian di atas, saya menyimpulkan bahwa sains Islam atau sains dan Islam from within adalah ilmu pengetahuan yang memiliki fondasi nilai spiritual sehingga secara internal manusia tidak mengalami kekosongan hidup. Fondasi ini adalah ikatan segitiga sacral-profound antara manusia, kosmos (alam semesta) dan Allah. Kita bukanlah makhluk satu-satu-Nya yang diberi keleluasaan atas alam semesta sehingga bisa melakukan segala hal sekehendak hatinya. Sebagai khalifah, manusia seharusnya memiliki tanggung jawab paling tinggi dalam menjaga keberlangsungan alam semesta. Narasi semacam inilah yang perlu dibangun dalam mengisi kekosongan eksistensi umat Islam. Narasi inilah yang seharusnya direproduksi dalam situasi ketidakpercayaan (beberapa) umat Islam yang seringkali bertindak defensif dan merasa terus-menerus menjadi korban (mentality of victim) zaman modern. Narasi inilah yang secara principal membuat peran agama (Islam) menjadi signifikan dalam mengembangkan sains.

Problem manusia modern anthropocentric mempunyai narasi egonya sendiri dalam hal penaklukan alam melalui kebanggaannya atas rasionalisme (sains). Rasionalitas manusia modern menganggap spesies non-manusia sebagai material $^{185}$ (hewan, tumbuhan, virus, bakteri, dan sejenisnya). Justru bagi manusia modern, manusia yang berpikir bahwa alam semesta ini perlu dihargai, dihormati, dan dipercayai memiliki energi kehidupan didefinisikan bodoh, mistis, irasional, dan terbelakang. Dari perspektif kehendak dan ego manusia

184. Ramadan, op.cit., hlm. 87.

185. Henri Lefebvre, Dialectical Materialism, terj. John Sturrock, USA: University of Minnesota Press, 2009. 
modern, Covid-19 adalah kesalahan yang lain bukan dampak dari tindakan manusia sejak era pencerahan, sains dan teknologi Barat atau industrialisasi (kapitalisme awal). Dengan kata lain, Covid-19 bukanlah hasil kesalahan manusia selama modernitas. Covid-19 adalah musuh manusia modern.

Padahal krisis modernitas di segala aspek kehidupan semakin terlihat jelas, termasuk kemunculan Covid-19 adalah salah tanda bukti manusia tidak memegang tanggung jawabnya dengan benar sebagai khalifah. Manusia kini tidak bisa mengendalikan dan mengatur alam semesta. Alam semesta adalah keteraturan yang perlu dipahami dan diperlakukan egaliter dengan semua makhluk, bukan dieksploitasi sebagai semata-mata materi demi konsumerisme. Dalam sains Islam, ekosistem dunia harus dilestarikan. ${ }^{186}$ Selain itu, alam semesta adalah refleksi dari atau kehadiran Allah. Namun kesadaran semacam ini justru disebut sebagai discourse terbelakang, irasional, dan superstitious dalam discourse kaum sekuler Barat.

Dalam krisis modernitas, manusia telah melampaui batas. Rasionalisme Barat dan praktik-praktik eksploitasi bumi oleh manusia tidak hanya membawa malapetaka terkait urusan perubahan iklim, tetapi juga kekacauan ekosistem, dan kemunculan Covid-19. Hal itu selaras dengan al Quran, surat Asy-Syuura: 27, berbunyi "Dan jikalau Allah melapangkan rezki kepada hamba-hambaNya, tentulah mereka akan melampaui batas di muka bumi, tetapi Allah menurunkan apa yang dikehendaki-Nya dengan ukuran. Sesungguhnya Dia Maha Mengetahui (keadaan) hamba-hamba-Nya lagi Maha Melihat”. Ayat (tanda) ini mengisahkan ilustrasi bahwa Allah sebenarnya telah mencukupi manusia, tetapi manusia lalai kepada Allah sehingga melampaui batasnya.

Walaupun ada fakta bahwa manusia menyalahkan Covid-19, fakta ini adalah suatu kewajaran bagi sifat alamiah manusia; manusia selalu berusaha self-defense dan protektif atas dirinya. Hal yang perlu digarisbawahi adalah Covid-19 tidak dengan sendirinya muncul, tetapi adanya intervensi manusia yang berlebihan (kapitalisme) atas alam semesta. Pertanyaan reflektif dari Allah yang tertulis dalam teks al Quran: "Maka apakah kiranya jika kamu berkuasa kamu akan membuat kerusakan di muka bumi dan memutuskan hubungan kekeluargaan?" (Muhammad:22). Di sini manusia mempunyai pilihan, apakah akan meneruskan tindakan destruktif terhadap alam atas nama pertumbuhan ekonomi dan

186. "COVID-19 pandemic, an 'unprecedented wake-up call' for all inhabitants of Mother Earth," https://news. un.org/en/story/2020/04/1062322, diakes 29 April 2020; Covid-19 tidak membawa hanya keburukan tetapi membantu keberlangsunagn alam, "7 things we've learned about Earth since the last Earth Day", https://www.vox.com/2020/4/22/21226521/earth-day-2020-climate-action-coronavirus-google-doodle 
kemajuan ataukah mundur secara proporsional demi keseimbangan manusia dengan alam?

Sains Islam memberi ruang reflektif bagi ilmuwan Islam untuk terus mencari kebenaran Allah (the Ultimate Divine), bukan pembenaran (verifikasi) dalam mengobservasi alam semesta yang sakral. Semakin tinggi level spiritual seseorang dalam beragama, maka semakin tinggi pula level rasionalitasnya dan dukungannya atas sains serta tingginya level pengendalian diri atas emosinya. ${ }^{187}$ Discourse inilah yang banyak ilmuwan Islam kontemporer kritisi atas dunia Barat dan dunia Islam. ${ }^{188}$

Saya pesimis terhadap kaum beragama yang ignore atas Covid-19, karena dari level eksistensinya, partisi ruang dan waktu hidupnya begitu berbeda dengan para ilmuwan Islam terdahulu di abad keemasan Islam. Saya juga belum melihat titik cerah bagaimana menghentikan modernitas kapitalisme global. Misalnya, ketika masa pandemi Covid-19 telah usai dengan ditemukan vaksin, maka mesin besar kapitalisme global akan mengolah vaksin ini menjadi alat traksaksi global demi keuntungan segelintir manusia (negara). Kehidupan pun berlangsung kembali seperti semula, yakni kaum beragama tetap secara eksistensial terancam ruang hidupnya dan spiritualismenya tengah direpresi baik secara kultural maupun psikologis oleh budaya konsumerisme. Sementara itu, kaum sekuler terus memiliki peluang mendefinisikan kaum beragama sebagai kelompok yang terbelakang yang penting untuk diawasi dan dikendalikan terus menerus demi eksistensi ke-sekuler-annya.

\section{Penutup}

Saya menekankan kembali kontribusi agama dalam menentukan sains dan sebaliknya. Di atas, saya paparkan bahwa keberagamaan kita untuk kasus yang tidak peduli atas bahaya Covid-19 adalah sikap defensif atas dirinya sendiri. Sikap defensif adalah pertunjukan sang diri yang lemah yang memerlukan self-defense dalam menghadapi modernitas. Dalam menghindari diri dari keputusasaan dan ketidakberdayaan zaman modern yang represif, maka agama menjadi 'alat' eksistensial mereka dalam memenuhi kekosongan dirinya. Agama menjadi eksistensi mereka dalam wujud identitas dan aliran pemikiran (mazhab) yang

187. Musa Maliki, "Spiritualitas, IImu, dan Emosi", https://news.detik.com/kolom/d-4585871/spiritualitas-ilmudan-emosi, diakses 2 Mei, 2020.

188. Mohammed Arkoun, Islam: To reform or to subvert? London: Saqi Books, 2006; Tariq Ramadan, The quest for meaning: Developing a philosophy of pluralism, UK: Penguin, 2012; Musa Maliki, Oksidentalisme: Pandangan Hassan Hanafi terhadap tradisi ilmu Hubungan Internasional Barat, Yogyakarta: Graha IImu, 2019. 
mereka rengkuh atau alami sebagai bagian dari dirinya. Jiwa, tubuh, imajinasi, dan spirit mereka terpusat pada agama. Problemnya, agama sendiri tereduksi dalam rangka menjadi 'senjata bertahannya' kaum keberagamaan ini. Dengan dalih agama yang mereka reduksi tanpa sadar, fakta baru dan rasionalitas tentang Covid-19 tidak akan mau diterima oleh mereka karena hal tersebut justru dipahami sebagai ancaman atas eksistensi hidup mereka. 'Label/ simbol/pemaknaan' agama yang mereka alami dan rengkuh adalah benteng pertahanan terakhir mereka dalam menghadapi kapitalisme global yang begitu represif, khususnya tradisi konsumerisme yang masuk ke dalam semua dimensi kehidupan.

Tindakan mereka memang kontra produktif dan justru membenarkan discourse sekularisme. Namun demikian, saya percaya pada tradisi Jawa tentang "agama itu ageman" (pakaian-pelindung tubuh dan sekitarnya) dan gaman (senjata-selfdefense). Mereka sulit menghadapi zaman konsumerisme yang begitu represif. Di era sekarang, belum ada sistem alternatif lain yang dapat menghadapi konteks kapitalisme global. Sebagian kaum beragama baru sampai pada level beradaptasi dan bernegosiasi dengan sistem kapitalisme global. Hal ini sangat ditentukan pula oleh partisi ruang dan waktu setiap penganut beragama yang berbeda-beda yang menjadikan masalah lebih rumit lagi.

Namun problem reduksi agama dan kapitalisme global tentunya tidak seharusnya diteruskan karena di level ekstrem keduanya bisa dapat saling menghancurkan atau salah satu sistem discourse tersebut secara sistemik menuju pada penghancuran diri sendiri. Dalam kondisinya yang terkendali, discourse kaum modern sekuler akan terus mendapat 'angin segar' untuk tetap mengontrol secara diskursif kaum beragama yang ignorance ke dalam definisi pengetahuannya melalui upaya reproduksi istilah-istilah baru secara terus menerus seperti "terbelakang”, "islamis", dan sebagainya.

Sedangkan sains dalam pengertian discourse modern sekuler justru bukan untuk keberlangsungan manusia bersama alam, tetapi untuk menopang sistem kapitalisme yang eksploitatif, konsumtif, dan materialistis. Discourse sekularisme menjadi fondasi doktrin sainstisme dan teknologi. Doktrin ini menjadi 'mitos' yang masih sulit diruntuhkan sebab manusia telah menjadikannya sebagai bagian dari eksistensi hidupnya sama halnya agama yang menjadi eksistensi bagi beberapa kaum beragama. Dalam doktrin ini, manusia tidak hanya dijauhkan dari alam, tetapi dijauhkan pula dari dirinya sendiri (alienation). Manusia dimaterialkan sama halnya alam semesta demi menopang sistem kapitalisme 
demi materialisme (materi tanpa batas). Singkatnya, doktirn sains dan teknologi yang obyektif justru secara instrumental menopang sistem kapitalisme global yang destruktif. Sistem kapitalisme memaksa teknologi dan sains untuk terus mengeksploitasi alam sampai pada titik di mana Covid-19 hadir menghentikan sistem tersebut untuk sementara waktu.

Oleh sebab itu, Islam dan sains from within menjadi suatu solusi metodologis -sebagai kekuatan diskursif. Kaum beragama (Islam), khususnya generasi baru beragama (Islam) dewasa ini diharapkan lahir dari partisi ruang dan waktu yang merujuk pada fakta sejarah ilmuwan islam. Dari discourse ilmuwan Islam, maka discourse yang direproduksi di masa depan adalah keselarasan antara ruang spiritual dan material, ruang imajinasi transcendental dan immanent, dan gairah ritual dan gairah rasionalitas serta ukhrawi dan duniawi (secular). Dengan demikian, proses penghayatan keberagamaan umat penting untuk selalu diawali dengan disiplin ketat dalam mempelajari agama secara bertahap melalui guru-guru yang tidak hanya secara pribadi dikenalnya, tetapi secara spiritual dan praktik keseharian menunjukkan ketaqwaannya.

Ilmuwan Muslim terdahulu mencari kebenaran (wujud) Allah melalui akalnya dalam format sains. Sains memberi prosedur dalam memaknai semesta sebagai kehadiran Allah sehingga alam semesta tidak diekploitasi dalam wujud sebagai materi, tetapi dimaknai secara mendalam dalam dimensi sacred dan Allah dalam dimensi the Ultimate Divine. Berpijak dari doktrin 'Tauhid' inilah intelektual Muslim bersama alam bisa harmonis dan saling menghargai. Dari discourse ilmuwan Muslim ini, pemaknaaan Covid-19 dapat secara disiplin dan proporsional ditempatkan pada posisi dan dimensinya secara tepat, tidak lagi secara serampangan dimaknai dan digeneralisasikan di ruang publik yang membawa implikasi luas terhadap umat.

Selain itu, problem titik temu Tauhid dengan teks skriptual agama lain menarik untuk menjadi bahan diskusi dan penelitian lebih lanjut yang juga penting demi menghindari benturan karena perbedaan. Titik temu dalam ruang dan waktu universal dan substantif adalah kunci utama agar discourse ilmuwan Islam terdahulu dapat dilestarikan. 


\section{Daftar Pustaka}

\section{Buku, Jurnal dan Kolom}

Arias-Maldonado, Manuel, Environment and Society Socionatural Relations in the Anthropocene, USA \& UK: Springer, 2015.

Arkoun, Mohammed, Islam: To reform or to subvert?, London: Saqi Books, 2006.

Armstrong, Karen, A Short history of myth, UK: Canongate Books Ltd, 2005.

Armstrong, Karen, The lost art of scripture, UK: the Bodley head, 2019.

Byrd, Dustin J., Islam in a post-secular society: religion, secularity, and the antagonism of recalcitrant faith, Boston: Brill, 2019.

De Roover, Jacob, Europe, India, and the limits of secularism, Oxford: Oxford University Press, 2015.

Eisenstadt, Samuel N., "Multiple modernities”. Daedalus, 2000 ,(1)129, hlm. 29-1; Samuel N. Eisenstadt, (2000), "The Reconstruction of religious arenas in the framework of multiple modernities, Millennium: Journal of International Studies, 2000 ,(3)29.

Esposito, John L., The Oxford dictionary of Islam, UK: Oxford University, 2003.

Hurd, Elizabeth Shakman, "Secularism and International Relations Theory", dalam Religion and International Relations Theory, diedit Jack Syder, USA: Columbia University Press, 2011.

Hurd, Elizabeth Shakman, The Politics of Secularism in International Relations, USA: Princeton University Press, 2008.

Kong, Wen-Hua, Yao Li, Ming-Wei Peng, De-Guang Kong, Xiao-Bing Yang, Leyi Wang, dan Man-Qing Liu, "SARS-CoV2-detection in patients with influenza-like illness", Nat Microbiol (2020).

Lefebvre, Henri, Dialectical materialism, terj. John Sturrock, USA: University of Minnesota Press, 2009.

Maclure, Jocelyn Maclure, "Towards a Political Theory of Secularism" dalam The sources of secularism: Enlightenment and beyond, diedit oleh A. Tomaszewska \& H. Hämäläinen, Switzerland: Palgrave Macmillan, 2007.

Maclure, Jocelyn, \& Taylor, Charles, Secularism and freedom of conscience, diterjemahkan Jane Marie Todd, USA: Harvard University Press, 2011.

Maliki, Musa, \& Azwar, Asrudin, Oksidentalisme: Pandangan Hassan Hanafi terhadap tradisi ilmu Hubungan Internasional Barat, Yogyakarta: Graha Ilmu, 2019.

Nasr, Sayyed Hossein, Islamic philosophy from its origin to the present: Philosophy in the land of prophecy, USA: State University of New York Press, 2006.

Nasr, Sayyed Hossein, Science and civilization in Islam, Chicago: ABC International Group Inc, 2001. 
Nasr, Sayyed Hossein, Traditional Islam in the modern world, USA \& UK: Kegan Paul International, 1994.

Ramadan, Tariq, Radical reform: Islamic ethics and liberation, Oxford: Oxford University Press, 2009.

Ramadan, Tariq, The quest for meaning: Developing a philosophy of pluralism, UK: Penguin, 2012.

Saad, Bashar, \& Said, Omar, Greco-Arab and Islamic herbal medicine: traditional system, ethics, safety, efficacy, and regulatory issues, USA: John Wiley \& Sons, Inc, hlm. 8

Saenong, Faried F., dkk, Fikih Pandemi: Beribadah di Tengah Wabah, Jakarta: NUO Publishing, 2020.

Shereen, Muhammad Adnan, \& Suliman Khan, Abeer Kazmi, Nadia Bashir, Rabeea Siddique, "COVID19- infection: Origin, transmission, and characteristics of human coronaviruses", Journal of Advance Research, Vol 2020,24 .

Stearns, Justin K., Infectious ideas: contagion in premodern Islamic and Christian thought in the Western Mediterranean, USA: The Johns Hopkins University Press, 2011.

Stewart, Katherine, The power of worshippers: Inside the dangerous rise of religious nationalism, New York: Bloomsbury Publishing, 2020.

Taylor, Charles, "Western secularity", dalam Rethinking secularism, diedit oleh Craig Calhoun, Mark Juergensmeyer, dan Jonathan VanAntwerpen UK: Oxford University, 2011

Taylor, Charles, "Why We Need a Radical Redefinition of Secularism", dalam The power of religion in the public sphere, diedit Eduardo Mendieta and Jonathan VanAntwerpen, USA: Columbia University Press, 2011.

\section{Media}

Muhammad Ilham Nafi'an, "Ustaz Somad Beri Penjelasan soal Anggapan 'Virus Corona Tentara Allah" https://news.detik.com/berita/d4920843-/ ustaz-somad-beri-penjelasan-soal-anggapan-virus-corona-tentara-allah diakes 13 April 2020

"MUI Bela Ustaz Abdul Somad soal Corona Tentara Allah", https://www. tagar.id/mui-bela-ustaz-abdul-somad-soal-corona-tentara-allah, diakses 13 April 2020

Jacobus E. Lato, "Coronavirus: God's Army and Pork Consumption in Indonesia”, https://www.gatestoneinstitute.org/15822/coronavirusindonesia, diakses 13 April 2020

Kate Walton, "Wuhan Virus Boosts Indonesian Anti-Chinese Conspiracies", https://foreignpolicy.com/31/01/2020/wuhan-coronavirus-boostsindonesian-anti-chinese-conspiracies/. 
M. Alvin Nur Choironi, "Quraish Shihab: Saya Tidak Setuju Pendapat Corona Tentara Allah”

https://islami.co/quraish-shihab-tidak-setuju-pendapat-corona-tentara-allah/, diakses 13 April 2020.

Roxanne Khamsi, "If coronavirus vaccine arrives, can the world make enough?" https://www.nature.com/articles/d8-01063-020-41586 diakses 13 April 2020.

Elissa Prichep, "Why a coronavirus vaccine takes over a year to produce - and why that is incredibly fast", https://www.weforum.org/agenda/04/2020/ why-a-coronavirus-vaccine-takes-over-a-year-to-produce-and-why-that-isincredibly-fast/, diakses 13 April 2020.

"WHO Director-General's opening remarks at the media briefing on COVID11 - 19- March 2020” https://www.who.int/dg/speeches/detail/ who-director-general-s-opening-remarks-at-the-media-briefing-on-covid-19-11-march2020-, diakses 13 April 2020.

Ewen Callaway, David Cyranoski, Smriti Mallapaty, Emma Stoye, Jeff Tollefson, The coronavirus pandemic in five powerful chats," https://www.nature. com/articles/d2-00758-020-41586, diakses 14 April 2020.

WHO, "Basic protective measures against the new coronavirus", https:// www.who.int/emergencies/diseases/novel-coronavirus2019-/advice-forpublic, diakses 14 April 2020

"Social Distancing, Quarantine, and Isolation", https://www.cdc.gov/ coronavirus/-2019ncov/prevent-getting-sick/social-distancing.html, diakses 14 April 2020.

"Coronavirus disease (Covid19-) Pandemic", https://www.who.int/ emergencies/diseases/novel-coronavirus2019-, diakses 13 April 2020.

Ben Simon, "Religion in conservative Mideast adapts to coronavirus" https:// www.thejakartapost.com/news/24/03/2020/religion-in-conservativemideast-adapts-to-coronavirus.html, diakses 15 April 2020.

Katherine Stewart, "The Religious Right's Hostility to Science Is Crippling Our Coronavirus Responsse”, https://www.nytimes.com/27/03/2020/ opinion/coronavirus-trump-evangelicals.html, diakses 15 April 2020.

Bil Browning, "Defiant pastor who kept church open despite coronavirus warnings dies a week later from COVID19-", https://www.lgbtqnation. com/04/2020/defiant-pastor-kept-church-open-despite-coronaviruswarnings-dies-week-later-covid19-/, diakses 15 April 2020.

Alex Bollinger, "Pastor who laid hands on Trump says avoiding coronavirus is for "pansies"” https://www.lgbtqnation.com/03/2020/pastor-laidhands-trump-says-avoiding-coronavirus-pansies/, diakses 14 April 2020. 
André Gagné, "Coronavirus: Trump and religious right rely on faith, not science", https://theconversation.com/coronavirus-trump-andreligious-right-rely-on-faith-not-science134508-, diakses 14 April 2020.

BBC, "Coronavirus: South Korea church leader apologises for virus spread", https://www.bbc.com/news/world-asia51701039-, diakses 14 April 2020.

Laura Bicker, "Coronavirus: South Korea sect leader to face probe over deaths", https://www.bbc.com/news/world-asia51695649-, diakses 15 April 2020

Ananthalakshmi, Joseph Sipalan, "How mass pilgrimage at Malaysian mosque became coronavirus hotspot", https://www.reuters.com/article/ushealth-coronavirus-malaysia-mosque/how-mass-pilgrimage-at-malaysianmosque-became-coronavirus-hotspot-idUSKBN2142S4, diakses 15 April 2020

"Petaling tabligh became Southeast Asia's Covid19- hotspot", https://www. nst.com.my/news/nation/575560/03/2020/how-sri-petaling-tablighbecame-southeast-asias-covid-19-hotspot, diakses 15 April 2020

Tashny Sukumaran "How the coronavirus spread at Malaysia's tabligh Islamic gathering”, https://www.scmp.com/news/asia/southeast-asia/ article/3075654/how-malaysias-sri-petaling-mosque-became-coronavirus, diakses 15 April 2020.

CNN Indonesia, "696 WNI Peserta Tabligh Akbar Malaysia Diimbau Tes Corona”, https://www.cnnindonesia.com/nasional/-20200314090234 -696/483346-20wni-peserta-tabligh-akbar-malaysia-diimbau-tes-corona diakses 15 April 2020.

CNBC Indonesia, "Corona di Tabligh Akbar, 696 WNI Diimbau Periksakan Diri,” https://www.cnbcindonesia.com/news/-4-20200314060024 144839/corona-di-tabligh-akbar-696-wni-diimbau-periksakan-diri, diakses 15 April 2020.

Antara, "Positif Corona, 17 WNI Jamaah Tabligh di India Masih Dirawat," https://nasional.tempo.co/read/1330023/positif-corona-17-wni-jamaahtabligh-di-india-masih-dirawat/full\&view=ok, diakses 15 April 2020.

Tom Allard dan Agustinus Beo Da Costa, "Muslim event in Indonesia stopped amid coronavirus fears", https://uk.reuters.com/article/uk-healthcoronavirus-indonesia-event/muslim-event-in-indonesia-stopped-amidcoronavirus-fears-idUKKBN21605S, diakses 15 April 2020.

Republika, “Tanpa Izin, Jamaah Tabligh Tetap Gelar Ijtima’ Dunia di Gowa”, https://republika.co.id/berita/q7e4lx327/tanpa-izin-jamaah-tablightetap-gelar-ijtima-dunia-di-gowa, diakeses 15 April 2020.

Miranti Kencana Wirawan, "Media Asing Sorot Jemaah Tabligh Indonesia: Kami Lebih Takut pada Tuhan”, https://www.kompas.com/global/ $\mathrm{read} / 073816170 / 19 / 03 / 2020 /$ media-asing-sorot-jemaah-tablighindonesia-kami-lebih-takut-pada-tuhan?page=all, diakses 15 April 2020. 
Amanda Hodge, "Coronavirus: Pilgrims inoculated by faith", https://www. theaustralian.com.au/world/coronavirus-pilgrims-inoculated-by-faith/ news-story/78f1f289378a52c077cb0371ac2cbc9d, diakses 15 April 2020.

Andi Hajramurni, "COVID19-: South Sulawesi cancels mass religious event, but not before thousands arrive on site", https://www.thejakartapost. com/news/19/03/2020/covid-19-south-sulawesi-cancels-mass-religiousevent-but-not-before-thousands-arrive-on-site.html, diakses 15 April 2020

Echa Panrita Lopi, "Peserta Ijtima Tabligh Dunia 2020 di Gowa Akan Diisolasi”, https://makassar.terkini.id/resmi-dibatalkan-peserta-ijtima-tablighdunia-2020-di-gowa-akan-diisolasi/, diakses 15 April 2020.

Edika Ipelona, "Diminta Ditunda Karena Virus Corona, Misa di Ruteng Tetap Berlangsung", https://www.kompas.tv/article/72090/diminta-ditundakarena-virus-corona-misa-di-ruteng-tetap-berlangsung, diakses 15 April 2020.

Robertus Belarminus, "Ini Alasan Misa Penahbisan Uskup Ruteng Tak Bisa Ditunda”, https://regional.kompas.com/read/12213691/19/03/2020/ ini-alasan-misa-penahbisan-uskup-ruteng-tak-bisa-ditunda, diakses 15 April 2020.

BBC, “Coronavirus: Does drinking tea help? https://www.bbc.com/news/ world-asia-india51910099-, diakses 15 April 2020.

DW, "Hindu group hosts cow urine drinking party to ward off coronavirus", https://www.dw.com/en/hindu-group-hosts-cow-urine-drinking-partyto-ward-off-coronavirus/a52773262-, diakses 15 April 2020

Danish Siddiqui, "Hindu group offers cow urine in a bid to ward off coronavirus", https://www.reuters.com/article/us-health-coronavirus-india-cow-urinepa-idUSKBN2110D5, diakses 15 April 2020.

BBC, "Coronavirus: Bangladesh mass prayer event prompts alarm," https:// www.bbc.com/news/world-asia51956510-, diakses 15 April 2020.

"Massive Bangladesh coronavirus prayer gathering sparks outcry", https://www. bangkokpost.com/world/1882015/massive-bangladesh-coronavirusprayer-gathering-sparks-outcry, diakses 15 April 2020.

Syahputra, Iswandi, "Ada Qadariyah dan Jabariyah dalam virus Corona", https://republika.co.id/berita/q7f80o385/ada-qadariyah-dan-jabariyahdalam-virus-corona, diakses 18 April 2020.

Asrudin Azwar dan Musa Maliki, "Covid19-, Agama, Dan Sains”, https:// geotimes.co.id/kolom/covid-19-agama-dan-sains/, diakses 30 April 2020.

Zacky Khairul Umam, "Korona, Antara Sains dan Agama”, Kompas, 10 Maret 2020

"Virus corona: Salat tarawih berjemaah dan hukuman cambuk di Aceh tetap berlangsung, 'transmisi lokal hanya masalah waktu'," https://www.bbc. com/indonesia/indonesia52406833-, diakses 26 April 2020. 
"Pandemi Covid19-, Warga Aceh Tetap Gelar Salat Tarawih Berjemaah di Masjid", https://www.liputan6.com/regional/read/4236145/pandemicovid-19-warga-aceh-tetap-gelar-salat-tarawih-berjemaah-di-masjid\#, diakses pada 26 April 2020.

Moch. Fiqih Prawira Adjie, "Indonesian Muslims hold congregational Ramadan prayers despite COVID19- warnings", https://www.thejakartapost.com/ news/26/04/2020/indonesian-muslims-hold-congregational-ramadanprayers-despite-covid-19-warnings.html?utm_term=Autofeed \&utm _ medium=Social\&utm_source=Facebook\#Echobox=1587889790, diakses, 26 April 2020.

Rachmawati, "Fakta Warga Nekat Panjat Pagar Masjid untuk Berjemaah, Diminta Pulang untuk Tarawih di Rumah”, https://regional.kompas. com/read/15500001/26/04/2020/fakta-warga-nekat-panjat-pagarmasjid-untuk-berjemaah-diminta-pulang-untuk, dikases 26 April 2020.

Hasrul Nawir, "Masjid di Parepare Sulsel Tetap Gelar Salat Jumat di Tengah Pandemi Corona", https://news.detik.com/berita/d4972340//masjiddi-parepare-sulsel-tetap-gelar-salat-jumat-di-tengah-pandemi-corona, diakses 26 April 2020.

Tri Subarkah, "Inilah Sejumlah Alasan Warga Tetap Tarawih Saat Pendemik Covid19.”, https://mediaindonesia.com/read/detail/-307362inilahsejumlah-alasan-warga-tetap-tarawih-saat-pendemik-covid19-, diakses 26 April 2020.

Martin Chulov, "Hajj pilgrimage could be cancelled because of coronavirus", https://www.theguardian.com/world/2020/apr/01/hajj-pilgrimagecould-be-cancelled-because-of-coronavirus-islamic

Idham Khalid, "Cegah Penyebaran Covid19-, Tarawih di Daerah Ini Jaga Jarak 1 Meter, Diberi Tanda Silang”, https://regional.kompas.com/ $\mathrm{read} / 22035021 / 23 / 04 / 2020 /$ cegah-penyebaran-covid-19-tarawih-didaerah-ini-jaga-jarak-1-meter-diberi, diakses pada 26 April 2020.

"COVID19- pandemic, an 'unprecedented wake-up call' for all inhabitants of Mother Earth,” https://news.un.org/en/story/1062322/04/2020, diakes 29 April 2020

"7 things we've learned about Earth since the last Earth Day", https://www.vox. com/21226521/22/4/2020/earth-day-2020-climate-action-coronavirusgoogle-doodle, diakses 29 Appril 2020.

Musa Maliki, "Spiritualitas, Ilmu, dan Emosi", https://news.detik.com/ kolom/d4585871-/spiritualitas-ilmu-dan-emosi, diakses 2 Mei, 2020.

Muhammad Subarkah, "Ide Karantina Dan Bapak Kedokteran Moderen, Ibnu Sina”, https://republika.co.id/berita/q90sno385/ide-karantina-danbapak-kedokteran-moderen-ibnu-sina, diakses 30 April 2020 
"Fatwa MUI No. 14 tahun 2020", https://mui.or.id/wp-content/ uploads/03/2020/Fatwa-tentang-Penyelanggaran-Ibadah-Dalam-siatuasiWabah-COVID19-.pdf, diakses 26 April 2020.

"MUI: Zona Hijau Corona Boleh Gelar Tarawih dengan Catatan" https:// www.cnnindonesia.com/nasional/496197-20-20200422163717/muizona-hijau-corona-boleh-gelar-tarawih-dengan-catatan, dikases 26 April 2020.

"MUI: Pelaksanaan Tarawih Menyesuaikan Kondisi di Daerah", https:// republika.co.id/berita/q96mz0327/mui-pelaksanaan-tarawihmenyesuaikan-kondisi-di-daerah, diakses 29 April 2020.

Muhammad Ilman Nafi'an, "Ungkit Kisah Nabi, MUI Minta Warga Salat Tarawih di Rumah" https://news.detik.com/berita/d4988807-/ungkitkisah-nabi-mui-minta-warga-salat-tarawih-di-rumah, diakses 29 April 2020.

Abdullah Alawi, "Darurat Covid19-, PBNU Imbau Masyarakat Shalat Tarawih di Rumah", https://www.nu.or.id/post/read/118670/darurat-covid-19pbnu-imbau-masyarakat-shalat-tarawih-di-rumah, diakses 26 April 2020.

Dadang Hermansyah, "Sejumlah Masjid di Ciamis Gelar Tarawih di Tengah Pandemi Corona", https://news.detik.com/berita-jawabarat/d4988914-/sejumlah-masjid-di-ciamis-gelar-tarawih-di-tengahpandemi-corona, diakses 26 April 2020.

Reny Mardika, "Warga Masih Gelar Tarawih di Masjid Dengan Protokol Covid19-," https://www.kompas.tv/article/77775/warga-masih-gelartarawih-di-masjid-dengan-protokol-covid19-, diakses 26 April 2020.

"Rapid Test Positif, Warga Jambi Masih Jadi Imam di Masjid," https://www. cnnindonesia.com/nasional/497316-20-20200426024720/rapid-testpositif-warga-jambi-masih-jadi-imam-di-masjid

"Positif COVID1 ,19- Warga Jambi Masih Aktif Jadi Imam Salat di Masjid", https://www.idntimes.com/news/indonesia/m-ramond/positif-covid-1-19warga-jambi-masih-aktif-jadi-imam-salat-di-masjid, diakses 26 April 2020.

"Haedar Ingatkan Masyarakat untuk \#Ramadandirumah," http://m. muhammadiyah.or.id/id/news-18881-detail-haedar-ingatkanmasyarakat-untuk-ramadandirumah.html?fbclid=IwAR0KmZTq8sSsnTK26HbyC6O_ZFntWCjQ0fEveJIXkHSxtn4bY7FGJFcxrM, diakses 26 April 2020.

"Muhammadiyah Imbau Tarawih di Rumah: Kenapa Ngotot di Masjid?" https:// www.cnnindonesia.com/nasional/495949-20-20200422090547/ muhammadiyah-imbau-tarawih-di-rumah-kenapa-ngotot-di-masjid, diakses 26 April 2020. 